\title{
PLFA Profiling of Microbial Community Structure Influencing Ecosystem Restoration in Chronosequence Iron Mine Overburden Spoil
}

\author{
Mamata Pasayat \\ School of Life Sciences, Sambalpur University, At/po- Jyoti Vihar, Burla, \\ Dist- Sambalpur, Pin- 768019, Odisha, India. \\ Dr. Amiya Kumar Patel \\ School of Life Sciences, Sambalpur University, At/po- Jyoti Vihar, Burla, \\ Dist- Sambalpur, Pin- 768019, Odisha, India.
}

\begin{abstract}
Phospholipid fatty acid analysis (culture-independent approach) provides a set of molecular markers for microbial taxa and consistently used to discriminate microbial communities of different origin and land uses. PLFA profiling provides an approach for microbial community assessment and their changes regulating ecosystem restoration. PLFAs are synthesized during microbial growth, rapidly degraded following cell death and hence can reliably reflect living microbial communities involved in ecosystem structure and function. Relative distribution of 75 PLFAs across the sites revealed significant differences in microbial community structure in seven different iron mine overburden spoil with variation in Shannon diversity index from $2.4905\left(\mathrm{IB}_{4}\right)$ to $2.8490\left(\mathrm{IB}_{2}\right)$ and Pielous evenness index from $0.7005\left(\mathrm{IB}_{0}\right)$ to $0.7556\left(\mathrm{IB}_{4}\right)$. The ratio of gram-positive to gram-negative exhibited a decline trend from $\mathrm{IB}_{\mathbf{0}}(\mathbf{2 . 1 2 9})$ to $\mathrm{IB}_{25}(1.137)$ over time. Fungal to bacterial ratio exhibited an increasing trend from $\mathrm{IB}_{0}(\mathbf{0 . 0 2 3 3})$ to $\mathrm{IB}_{25}$ $(\mathbf{0 . 0 6 4 0 )}$ and was found to be higher in NF soil (0.1116), revealing the sign of ecosystem restoration over time. F:B ratio showed positive correlation with $\mathrm{pH}(\mathrm{r}=\mathbf{0 . 8 7 2}, \mathrm{p}<0.001)$, moisture $(r=0.888, p<0.001)$. Based on the relative distribution of PLFAs, the principal component analysis and cluster analysis can able to discriminate different mine overburdens into independent clusters. Redundancy analysis can contribute for soil quality assessment based on the shift in 75 PLFAs. Thus, PLFA profiling evaluated the broad scale patterns of distribution of microbial community structure influencing soil quality and can be used for monitoring the restoration of iron mine spoil over time.
\end{abstract}

Keywords: Iron mine spoil; microbial community structure; PLFA; reclamation.

\section{INTRODUCTION}

Soil microbial community structure is being marked as ecologically relevant endpoint and realistically incorporated for assessment of potential risks associated with anthropogenic disturbances, which influence microbial community composition at multiple spatial extent and are linked closely to soil environmental heterogeneity [1]. The shift in microbial community structure and composition is regarded as sensitive indicator of microbial activity reflecting soil quality [2]. Microbial community structure is also considered as an inherent factor in determining the biogeochemical cycles and organic matter turnover in soil [3]. Besides, the assessment of microbial community composition is pre-requisite to determine biodiversity, ecological structure and sustainability [4]. Microbial community dynamics provides information about the soil quality status. Soil exhibiting higher microbial diversity is the characteristic feature of fertile soil subsystem where the microbes are the key players involved in nutrient turnover [5]. In contrast, the degraded soil with low microbial diversity is often hardly responds to environmental changes [6]. Therefore, it is essential to quantify the relationship between microbial community structure and ecosystem function.

An approach to detect possible changes in soil microbial community can be analyzed through PLFA profiling [7]. PLFA analysis is culture-independent approach in order to determine the variation in microbial community composition and used as an approximation for taxonomic diversity assessment [7-11]. PLFA analysis has been applied to elucidate different strategies employed by soil microorganisms to adapt the changed environment along fertility gradient [12], management practices under wide range of perturbations and alliance with changes in vegetation during succession [13-14]. Different subsets of microbes have unique PLFA patterns, which reflect microbial community fingerprint to determine the characteristic features of microbial community directly in natural habitat [14]. Community-level PLFA profiles have been found to be useful in detecting the responses of soil microbial communities with respect to the variation in land use patterns or disturbances [1517]. PLFA analysis can reliably reflect the biomass of microbial community as it is exclusively found in cell membrane of microbes. However, the detection and interpretation of decline in PLFA abundance is difficult 
since it assumes the degradation of their phospholipids rapidly to diglycerides following cell death [18-19]. Therefore, the PLFA content is used as an index of viable microbial biomass [20-22]. Besides, the analysis of microbial populations by PLFA profiling provides direct information about their identification, classification and microbial community composition, which overcomes the problems associated with the culture techniques [23]. PLFA profile does not provide actual species composition but instead reflects the overall microbial community structure [24].

Phospholipid composed of single molecule of glycerol with two $\mathrm{OH}$ groups being replaced by two fatty acids by ester or ether linked showing the properties of hydrophobic tail, whereas third $\mathrm{OH}$ group is linked with phosphate group representing hydrophilic head. Microbial fatty acids are $\mathrm{C}_{12}$ to $\mathrm{C}_{24}$ long but the membrane fatty acids are usually $\mathrm{C}_{14}$ to $\mathrm{C}_{20}$ long [22]. PLFA can be grouped into ester-linked phospholipid (EL-PLFAs, 60$90 \%$ ) and non-ester linked phospholipid (NEL-PLFAs, 10-40\%) fatty acids. EL-PLFAs are subdivided into ester-linked unsubstituted (EL-UNFAs) and hydroxyl substituted (EL-HYFAs) fatty acids. EL-UNFA includes saturated (EL-SATFA), monounsaturated (EL-MUFA) and polyunsaturated (EL-PUFA) fatty acids. EL-SATFA has two sub-groups: branched chain (BRANCs) and straight chain (STRAs) fatty acids. NEL-PLFAs include unsubstituted (NEL-UNFA) and hydroxyl substituted (NEL-HYFA) fatty acids [13]. Phospholipids can exist with varying chain length, saturation and branching [25]. Even though phospholipids occur in different life forms, the fatty acid side chains between life forms are quite unique. Polyunsaturated fatty acids (18:3 $\omega 3 \mathrm{c})$ are found in plants and cyanobacteria but are not present in bacteria. Monounsaturated $(\omega-7)$, odd-chain saturated $(15: 0)$, branched-chain (iso/anetiso and 10-methyl) and cyclopropane (19:0 cyclo $\omega 7 \mathrm{c})$ fatty acids are mostly synthesized by bacteria [25] and therefore used for microbial community fingerprint [26-28]. The fatty acid extracted from sediments can able to classify distinct microbial groups such as microeukaryotes (PUFA), aerobic prokaryotes (MUFA), gram-positive and anaerobic bacteria (saturated and branched fatty acids; $\mathrm{C}_{14^{-}}$ $\mathrm{C}_{16}$ ), gram-positive bacteria (branched-chain fatty acids; iso/anteiso). Besides, LPS-OH fatty acids were used as reliable indicators of gram-negative bacteria because of their existence in lipid portion of lipopolysaccharides in cell wall [29].

The total amount of PLFAs was used to indicate the total microbial biomass and the sum of PLFAs $(14: 0,15: 0,16: 0,17: 0,18: 0,18: 1 \omega 9 c, 20: 0,21: 0,22: 0$ and 24:0) was considered to be predominantly of

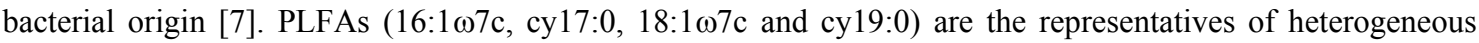
groups of soil microbes most prevalent in gram-negative bacteria [30-32], the iso and antesio branched PLFAs

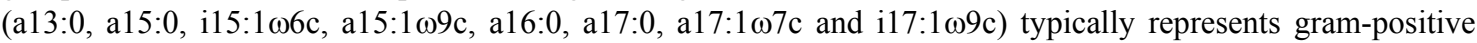
bacteria [31-32]. Besides, sulfate-reducing bacteria including other anaerobic bacteria were represented by saturated and branched $\left(\mathrm{C}_{16}-\mathrm{C}_{19}\right)$ fatty acids [33]. PLFAs $(18: 1 \omega 9 \mathrm{c}, 18: 2 \omega 6 \mathrm{c}$ and 18:3 $\omega 6 \mathrm{c})$ are used to represent common fungi [31-32, 34-35]. The unsatured fungal biomarker $16: 1 \omega 5 \mathrm{c}$ is typical for arbuscular mycorrhizal

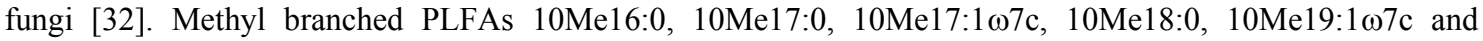

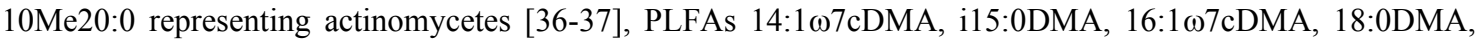

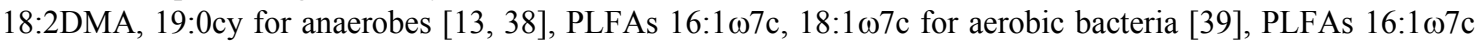

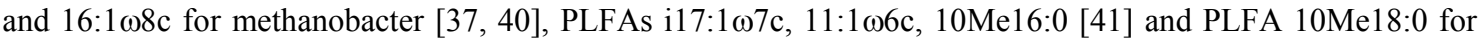
sulfate reducing bacteria $[13,42]$.

PLFA profiling is rapid and reliable way of assaying the biomass and composition of microbial communities [43-44]. Besides, it is considered as more sensitive and reproducible technique to quantify the shift in microbial community composition and soil nutritional/physiological status compared to culture dependent methods [4]. The shift in PLFAs can reflect overall changes in microbial community structure, which can be used as indicators of disturbances and provided valuable information regarding the implementation of reclamation strategies [45-48]. Besides, PLFAs represent set of molecular markers for different microbial taxonomic groups [27, 49-50]. Thus, PLFA profiling provides an accurate census of the current living communities in the ecosystem [50-51]. Keeping in view, the present investigation was designed to provide comparative assessment of microbial community structure in seven iron mine overburden spoil in chronosequence over time and the nearby forest soil. Further, the fungal to bacterial PLFAs and gram-positive to gram-negative PLFAs ratio within the soil microbial communities were estimated not only to determine the reclamation progress but also to understand the relationship between microbial community structure and ecosystem function.

\section{A. Study site}

\section{MATERIALS AND METHODS}

The present study was carried out in iron mining area located at Noamundi in the revenue district of West Singhbhum, Jharkhand, India ( $85^{\circ} 28^{\prime} 02.61^{\prime \prime}$ east longitude and $22^{\circ} 8^{\prime} 33.93^{\prime \prime}$ north latitude) (Figure 1). The study site is situated away from the mean sea level i.e. about $581 \mathrm{~m}$ altitude with the mean annual temperature $19.67^{\circ} \mathrm{C}$ and humidity $20 \%$. Tropical dry deciduous forest is considered to be natural vegetation of the area. However, extensive iron mining activities led to decline of forest cover and generated a number of 
abandoned iron mine overburdens. In the present study, seven iron mine overburdens in chronosequence have been selected based on the time elapsed since inception such as fresh iron mine spoil $\left(\mathrm{IB}_{0}\right), 2 \mathrm{yr}\left(\mathrm{IB}_{2}\right), 4 \mathrm{yr}\left(\mathrm{IB}_{4}\right)$, $6 \mathrm{yr}\left(\mathrm{IB}_{6}\right)$, 8yr $\left(\mathrm{IB}_{8}\right), 15 \mathrm{yr}\left(\mathrm{IB}_{15}\right)$, and $25 \mathrm{yr}\left(\mathrm{IB}_{25}\right)$. Besides, the nearby native forest soil (NF) adjacent to core mining area was selected for comparison.

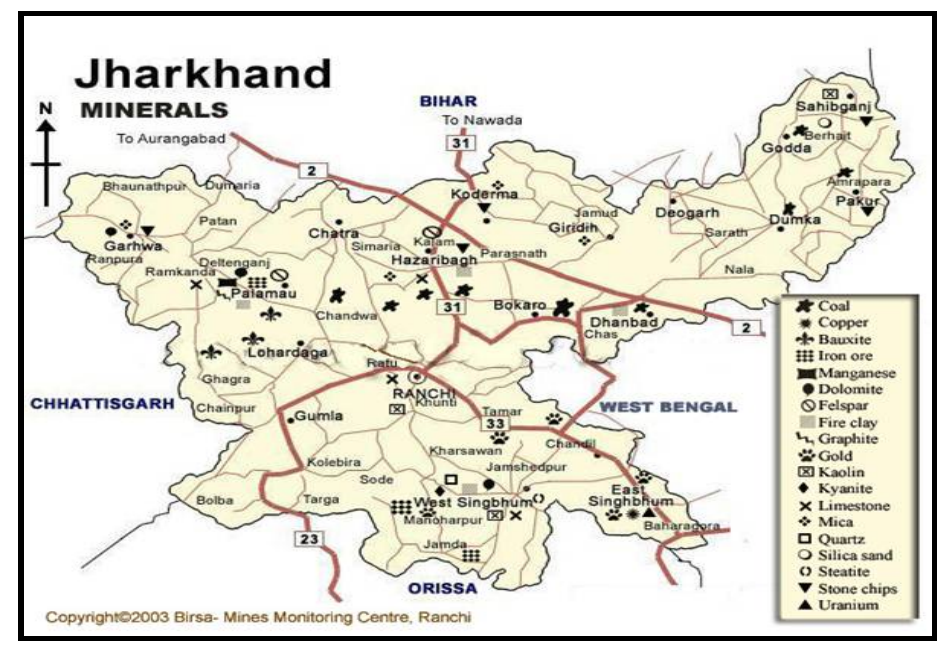

Figure 1. Geographical location and mineral map of the study site, Jharkhand.

\section{B. Mine spoil sampling}

Spoil sampling was done in accordance with the microbiological method from seven different age series iron mine overburdens $\left(\mathrm{IB}_{0}, \mathrm{IB}_{2}, \mathrm{IB}_{4}, \mathrm{IB}_{6}, \mathrm{IB}_{8}, \mathrm{IB}_{15}\right.$ and $\left.\mathrm{IB}_{25}\right)$ and $\mathrm{NF}$ soil [52]. Each site was divided into 3 blocks and five mine spoil samples were collected randomly from $0-15 \mathrm{~cm}$ soil depth by digging pits of 15 $\mathrm{cm}^{3}$ size, which is referred as 'sub-samples' and mixed thoroughly to form 'composite sample'. Similar sampling strategies have been followed to obtain three composite samples from different age series iron mine overburden. The samples were subjected to sieving $\left(0.2 \mathrm{~mm}\right.$ mesh) and stored at $4^{\circ} \mathrm{C}$ for further analysis.

\section{Phospholipid fatty acid (PLFA) analysis}

Lipids extraction based on fractionation and quantification was performed [53], which is simple, fast and used for microbial community analysis including non-culturable microbes. Lyophilized soil sample (5g dry weight) was sonicated with phosphate buffer, methanol and chloroform (4:10:5 v/v/v) for 10 min in sonicating water bath at room temperature and rotated end over end for $2 \mathrm{hr}$. The mixture was centrifuged at $2500 \mathrm{rpm}$ for $10 \mathrm{~min}$ and liquid phase was transferred followed by addition of equal volume of distilled water and chloroform $(5: 5 \mathrm{v} / \mathrm{v})$, shaken vigorously and incubated for $24 \mathrm{hr}$ for separation of phases. The bottom organic phase was evaporated under nitrogen $\left(\mathrm{N}_{2}\right)$ and stored at $-20^{\circ} \mathrm{C}$. Lipid fractions were separated by solid phase extraction (SPE) chromatography by washing the silica gel column with chloroform. After loading the extract in chloroform the neutral, glyco and phospholipids were eluted with chloroform, acetone and methanol respectively followed by the evaporation of the phospholipids fraction under $\mathrm{N}_{2}$ and stored at $-20^{\circ} \mathrm{C}$. The transesterification of fatty acids was performed with equal volume of methanol and toluene $(1: 1 \mathrm{v} / \mathrm{v})$ following alkaline methanolysis of phospholipids by methanolic $\mathrm{KOH}$ at $37^{\circ} \mathrm{C}$ for $15 \mathrm{~min}$. The resulting ester-linked fatty acid methyl esters (FAME) was dissolved in isooctane or hexane, acetic acid and double distilled water mixture $(2: 0.3: 2 \mathrm{v} / \mathrm{v} / \mathrm{v})$ and vortexed. The top (organic) phase was removed following the extraction process repeatedly with addition of hexane and the combined phase was evaporated under $\mathrm{N}_{2}$ and stored at $-20^{\circ} \mathrm{C}$. The extracts were cleaned using $\mathrm{NH}_{2}$ SPE column and the samples were dissolved in equal volume of hexane: methyl tertbutyl ether $(1: 1 \mathrm{v} / \mathrm{v})$ and quantified through GC-MS.

PLFA nomenclature follows the common convention of $\mathrm{A}: \mathrm{B} \omega \mathrm{C}$ [54], where the total number of $\mathrm{C}$ atoms in the fatty acids is denoted as ' $\mathrm{A}$ ' and the number of double bonds as ' $\mathrm{B}$ '. The position of the double bond is defined by a symbol ' $\omega$ ' followed by the number of carbons ' $C$ ' from the methyl end of fatty acid molecule. The prefixes cis and trans configuration are indicated by $\mathrm{c}$ and $\mathrm{t}, \mathrm{i}$ and a refer to iso and anteiso branching, $b r$ indicates an unknown methyl branch position, cy refers to cyclopropyl fatty acids. Hydroxyl groups are indicated by ' $\mathrm{OH}$ '. The $10 \mathrm{Me}$ indicates the presence of methyl group in $\mathrm{C}_{10}$ from the carboxyl end of the fatty acid [55-56].

\section{Statistical analysis}


PLFA profiles were analyzed using Sherlock PLFA tool (Version 1.1). Shannon's diversity index or Shannon-Weaver index $(H)$ was calculated as $\left(-\Sigma p_{i} \ln p_{i}\right)$, where $p_{i}$ is the peak area of $i^{\text {th }}$ peak over the area of all peaks. Pielou's evenness index $(J)$ was calculated as $(H / H m a x)$, where $H$ is the no. derived from Shannon diversity index and Hmax is the maximum value of $H(H \max =\ln R ; R$ denotes PLFA richness). Principal component analysis was performed in order to discriminate seven iron mine overburdens based on the relative distribution PLFAs across the sites using SPSS (Version 18.0). Besides, cluster analysis using distance matrix based on the relative distribution of 75 PLFAs across the sites was performed to illustrate the relatedness among them. RDA was performed using XLSTAT-2014 (Version 2.03).

\section{RESULTS AND DISCUSSION}

Community level PLFA profiling has been used to determine the qualitative as well as quantitative changes in soil, which provides broad diversity measure of microbial community composition associated with their activities and the nature of interaction among them in terrestrial ecosystems [4, 16, 17, 19, 57]. Besides, the existence of different functional groups responds differently to prevailing environmental conditions in different ecosystems, which affects the microbial community composition. Certain PLFAs with specific functional groups are used as potential biomarkers for fingerprinting the existence of microbial communities based on the relative abundance of soil microorganisms [31-32, 37, 42, 50, 58-59].

\section{A. PLFA profiles of mine spoil}

The relative contribution of 75 PLFAs representing microbial community structure across seven different age series iron mine overburden spoil in chronosequence and nearby NF soil revealed marked variation (Table 1). It is evident that the PLFA profiles were dominated by saturated fatty acids $(14: 0,15: 0,16: 0,17: 0$ and 18:0), branched saturated fatty acids (i15:0, a15:0, i16:0 and i17:0), cyclopropyl fatty acids (cy17:0 and

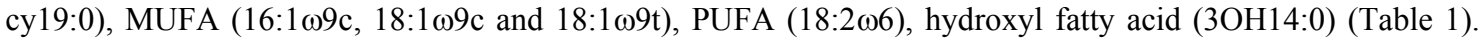

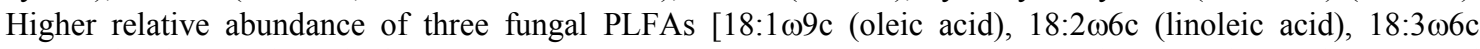
(gammalinoleic acid)], which accounted for $4.19 \%, 1.98 \%$ and $0.97 \%$ respectively were observed in NF soil [31-32, 35, 37, 60]. PLFA 18:1 $\omega 9 \mathrm{c}$ is reported to be most common in fungal species [13]. High prevalence of fungal PLFA in NF soil may be attributed to the availability of higher amount of recalcitrant polymeric phenolic compounds such as lignin and tannin and principally responsible for lignin degradation [61]. Similarly, higher relative abundance of arbuscular mycorrhizal fungal PLFA 16:1 $15 \mathrm{c}$ (cis-11-palmitoleic acid) were estimated in NF soil (6.15\%) compared to different age series iron mine overburden spoil [32]. PLFA 16:1 $15 \mathrm{c}$ derived from arbuscular mycorrhizal fungi is known to contribute substantially to fungal biomass in NF soil [60], which is influenced by the changes occur in soil organic $\mathrm{C}[51,62]$. The methyl branched PLFAs representing actinomycetes (10Me16:0, 10Me22:0, 10Me18:0 and 10Me17:1 $107 \mathrm{c})$ were not detected in NF soil (Table 1) [13, 36-37]. Higher relative abundance of methanobacter PLFA 16:1 $17 \mathrm{c}$ was exhibited by NF soil compared to different iron mine overburden spoil [37].

Table 1. Percentage composition of 75 PLFAs in the seven different age series iron mine overburden spoil as well as nearby NF soil.

\begin{tabular}{|c|c|c|c|c|c|c|c|c|}
\hline PLFAs & $\mathrm{IB}_{0}$ & $\mathrm{IB}_{2}$ & $\mathrm{IB}_{4}$ & IB6 & $\mathrm{OB}_{8}$ & $\mathrm{OB}_{15}$ & $\mathrm{OB}_{25}$ & NF \\
\hline $10: 00$ & 0.17 & 0.29 & 0 & 0 & 0 & 0 & 0 & 0 \\
\hline $10: 03 \mathrm{OH}$ & 0 & 0.31 & 0 & 0 & 0 & 0 & 0 & 0 \\
\hline $11: 00$ & 0 & 0 & 0.71 & 0.56 & 0 & 0 & 0 & 0 \\
\hline a11:0 & 0 & 0 & 3.1 & 2.45 & 0 & 0 & 0 & 0.7 \\
\hline i11:0 & 0 & 0 & 0 & 1.15 & 1.22 & 0 & 0 & 0 \\
\hline $12: 00$ & 26.7 & 0 & 27.25 & 26.68 & 24.12 & 25.62 & 29.58 & 13.08 \\
\hline a13:0 & 2.21 & 2.46 & 2.99 & 1.57 & 1.69 & 1.8 & 2.56 & 3.36 \\
\hline 13:0 DMA & 0 & 0.13 & 0 & 0 & 0 & 0 & 0 & 0 \\
\hline $13: 1 \mathrm{w} 4 \mathrm{c}$ & 0.21 & 0.3 & 0.49 & 0.38 & 0 & 0.3 & 0.3 & 1.27 \\
\hline $13: 1 \mathrm{w} 5 \mathrm{c}$ & 0 & 0 & 0 & 0 & 0.21 & 0 & 0 & 0 \\
\hline $14: 00$ & 0.95 & 1.03 & 1.26 & 1.13 & 0.85 & 2.48 & 1.12 & 1.67 \\
\hline i14:0 & 0.7 & 0 & 0 & 0 & 0 & 0 & 0 & 0.31 \\
\hline a14:0 & 0.19 & 0 & 0 & 0.11 & 0.13 & 0.13 & 0.29 & 0.23 \\
\hline 14:0 DMA & 0.26 & 0 & 0 & 0.14 & 0.21 & 0 & 0.19 & 0 \\
\hline $14: 1 w 8 c$ & 0.31 & 0.28 & 0 & 0.25 & 0.27 & 0.2 & 0.23 & 0.48 \\
\hline $14: 1 \mathrm{w} 5 \mathrm{c}$ & 0.39 & 0.63 & 0 & 0.25 & 0.39 & 0.22 & 0.28 & 0.24 \\
\hline $15: 00$ & 0.18 & 0.22 & 0 & 0.21 & 0.21 & 0.36 & 0.21 & 0.97 \\
\hline a15:0 & 3.13 & 3.66 & 4.8 & 2.57 & 2.73 & 3.04 & 3.84 & 4.26 \\
\hline 15:0 DMA & 0 & 0 & 0 & 0 & 0.23 & 0 & 0 & 0 \\
\hline i15:0 DMA & 0.2 & 0.37 & 0 & 0.25 & 0.19 & 0.16 & 0.2 & 0.31 \\
\hline i15:1 w9c & 0.38 & 0 & 0 & 0.23 & 0.33 & 0 & 0.35 & 0 \\
\hline a15:1 w9c & 0.37 & 0.41 & 0 & 0.27 & 0.33 & 0.31 & 0.31 & 0 \\
\hline $15: 1 \mathrm{w} 8 \mathrm{c}$ & 0.62 & 0.52 & 0.48 & 0.31 & 0.36 & 0.42 & 0.48 & 0 \\
\hline $15: 1 \mathrm{w} 9 \mathrm{c}$ & 0 & 0.26 & 0 & 0.22 & 0.19 & 0.14 & 0.15 & 0 \\
\hline
\end{tabular}




\begin{tabular}{|c|c|c|c|c|c|c|c|c|}
\hline $15: 3 \mathrm{w} 3 \mathrm{c}$ & 0 & 21.54 & 0 & 0 & 0 & 0 & 0 & 0 \\
\hline $16: 00$ & 10.44 & 14.28 & 4.53 & 11.15 & 13.52 & 17.13 & 9.94 & 5.25 \\
\hline i16:0 & 0 & 0 & 0 & 0 & 0.13 & 0.32 & 0.3 & 0.54 \\
\hline $16: 02 \mathrm{OH}$ & 0 & 0 & 0.77 & 0 & 0 & 0 & 0 & 0 \\
\hline 16:0 $\mathrm{N}$ alcohol & 1.06 & 10.07 & 0.83 & 0.95 & 1.22 & 0.92 & 0.92 & 1.41 \\
\hline 10 Me16:0 & 0.51 & 0.69 & 0 & 0 & 0 & 0.66 & 0 & 0 \\
\hline $16: 1 \mathrm{w} 5 \mathrm{c}$ & 0 & 0.41 & 0 & 0 & 0 & 0.35 & 0.7 & 6.15 \\
\hline $16: 1 \mathrm{w} 7 \mathrm{c}$ & 0 & 1.23 & 0 & 0 & 0 & 0.67 & 0.81 & 1.25 \\
\hline 16:1 w7c DMA & 0 & 0 & 0 & 0 & 5.88 & 0 & 4.82 & 7.67 \\
\hline 16:1 w9c DMA & 5.68 & 7.32 & 1.64 & 0.95 & 0 & 0 & 0 & 0 \\
\hline 16:2 DMA & 2.04 & 2.36 & 3 & 2.95 & 2.91 & 2.36 & 2.49 & 2.54 \\
\hline $17: 00$ & 0 & 0 & 0 & 0 & 0.2 & 0.96 & 0.42 & 0.49 \\
\hline a17:0 & 2.24 & 0 & 3.81 & 3.64 & 2.1 & 2.45 & 2.93 & 2.84 \\
\hline $17: 0$ cy w $7 \mathrm{c}$ & 0 & 0.77 & 0 & 0 & 0 & 0 & 0 & 0 \\
\hline $17: 1 \mathrm{w} 5 \mathrm{c}$ & 0.25 & 0 & 0.43 & 0.32 & 0.29 & 0.35 & 0.32 & 0 \\
\hline a17:1 w7c & 0.42 & 0.68 & 0.66 & 0.37 & 0.48 & 0.46 & 0.52 & 0.61 \\
\hline i17:1 w9c & 1.73 & 3.98 & 0.47 & 0.54 & 0.76 & 0.34 & 0.45 & 0.75 \\
\hline 10 Me $17: 1 \mathrm{w} 7 \mathrm{c}$ & 0 & 0.17 & 0 & 0 & 0 & 0 & 0 & 0 \\
\hline $17: 1 \mathrm{w} 8 \mathrm{c}$ & 0 & 0.6 & 0 & 0 & 0 & 0.66 & 0 & 0 \\
\hline 18:00 & 5.97 & 7.46 & 2.65 & 6.21 & 7.9 & 10.94 & 4.67 & 5.93 \\
\hline 18:0 DMA & 0.15 & 0.24 & 0 & 0 & 0 & 0 & 0.16 & 0 \\
\hline $10 \mathrm{Me} 18: 0$ & 0 & 0 & 0 & 0 & 0 & 0.15 & 0.15 & 0 \\
\hline $18: 1 \mathrm{w} 5 \mathrm{c}$ & 0.28 & 0 & 0 & 0 & 0.22 & 1.28 & 0.75 & 1.62 \\
\hline $18: 1 \mathrm{w} 7 \mathrm{c}$ & 0.62 & 1.44 & 0 & 0.55 & 0.6 & 0.73 & 0.96 & 1.01 \\
\hline $18: 1 \mathrm{w} 9 \mathrm{c}$ & 2.64 & 3.62 & 2.67 & 3.14 & 3.11 & 5.96 & 3.25 & 4.19 \\
\hline 18:2 DMA & 0.2 & 0.24 & 0 & 0 & 0.18 & 0.14 & 0 & 0 \\
\hline $18: 2 \mathrm{w} 6 \mathrm{c}$ & 0.63 & 0.91 & 0.43 & 0.78 & 0.78 & 1.03 & 0.88 & 1.98 \\
\hline $18: 3 \mathrm{w} 6 \mathrm{c}$ & 0.83 & 1.02 & 0.97 & 0.86 & 1.34 & 1.14 & 0.8 & 0.97 \\
\hline 19:0 cy w7c & 0.2 & 0.45 & 0 & 0.21 & 0.23 & 0.27 & 0.36 & 0.52 \\
\hline $19: 0$ cy w9c & 0 & 0 & 0 & 0 & 0 & 0.12 & 0 & 0 \\
\hline $19: 1 \mathrm{w} 8 \mathrm{c}$ & 0.18 & 0 & 0.43 & 0.31 & 0.18 & 0.28 & 0.29 & 0.31 \\
\hline $19: 3 \mathrm{w} 3 \mathrm{c}$ & 11.25 & 0 & 20.54 & 11.08 & 10.14 & 10.89 & 15.12 & 10.22 \\
\hline $19: 3$ w6c & 0.42 & 0 & 0 & 0 & 0.39 & 0 & 0 & 0 \\
\hline $20: 00$ & 0.26 & 0.86 & 3.15 & 1.98 & 0.25 & 0.76 & 0.66 & 0.86 \\
\hline $20: 1 \mathrm{w} 4 \mathrm{c}$ & 0.27 & 0.38 & 0.57 & 0.33 & 0.27 & 0.33 & 0.5 & 0.61 \\
\hline $20: 1 w 9 c$ & 0.16 & 0.27 & 0 & 0.21 & 0.15 & 0 & 0.39 & 0.41 \\
\hline $20: 3$ w6c & 0.25 & 0 & 0 & 0 & 0 & 0.24 & 0 & 0 \\
\hline $21: 00$ & 0 & 0 & 0 & 0 & 0 & 0.12 & 0 & 0 \\
\hline $21: 1 \mathrm{w} 3 \mathrm{c}$ & 0 & 0 & 0 & 0 & 0 & 0 & 0.39 & 0 \\
\hline $21: 1 \mathrm{w} 5 \mathrm{c}$ & 0 & 0 & 0 & 0 & 0 & 0.19 & 0 & 0 \\
\hline $21: 1 \mathrm{w} 8 \mathrm{c}$ & 0.21 & 0.38 & 0.51 & 0.42 & 0.23 & 0.15 & 0.41 & 0.45 \\
\hline $21: 3 \mathrm{w} 3 \mathrm{c}$ & 7.95 & 0 & 0 & 7.34 & 7.18 & 0 & 0 & 8.05 \\
\hline $22: 00$ & 0.32 & 0.21 & 0 & 0.23 & 0.28 & 0.94 & 1.13 & 1.27 \\
\hline i22:0 & 0 & 0 & 0 & 0 & 0 & 0.7 & 0.39 & 0.42 \\
\hline $10 \mathrm{Me} 22: 0$ & 0.22 & 0.26 & 0 & 0.24 & 0.19 & 0 & 1.3 & 0 \\
\hline $22: 1 \mathrm{w} 9 \mathrm{c}$ & 0.34 & 0 & 0 & 0 & 0.33 & 0 & 0 & 0.24 \\
\hline 23:00 & 0 & 0 & 0 & 0 & 0 & 0.15 & 0 & 0 \\
\hline $23: 3 w 3 c$ & 4.89 & 6.68 & 10.85 & 6.33 & 4.33 & 0 & 0 & 3.04 \\
\hline $23: 4 \mathrm{w} 6 \mathrm{c}$ & 0.28 & 0.38 & 0 & 0 & 0.39 & 0 & 0 & 0.43 \\
\hline $24: 00$ & 0.16 & 0.22 & 0 & 0.18 & 0.18 & 0.68 & 1.08 & 1.09 \\
\hline $24: 3 w 3 c$ & 0 & 0 & 0 & 0 & 0 & 0 & 1.65 & 0 \\
\hline
\end{tabular}

\section{B. Distribution of PLFAs}

PLFA pattern is used to describe the microbial community composition in different age series iron mine overburden spoil in chronosequence as well as nearby NF soil, grouped into distinct categories such as microeukaryotes (PUFA), aerobic prokaryotes (MUFA), gram-positive and other anaerobic bacteria (saturated and branched fatty acids ranges from $\mathrm{C}_{14}$ to $\mathrm{C}_{16}$ ), anaerobic bacteria (saturated and branched fatty acids ranges from $\mathrm{C}_{16}$ to $\mathrm{C}_{19}$ ) (Table 2) [4, 33]. The PUFAs are considered as the signature fatty acids for eukaryotes, which range from $21.55 \%\left(\mathrm{IB}_{25}\right)$ to $33.61 \%\left(\mathrm{IB}_{4}\right)$. MUFAs representing aerobic prokaryotes can occur both in gram-negative and gram-positive bacteria that ranges from $10.12 \%\left(\mathrm{IB}_{8}\right)$ to $15.53 \%\left(\mathrm{IB}_{2}\right)$. However, their relative contribution to total PLFA in gram-positive bacteria was found to be minimal (20\%) and hence MUFAs can be considered as biomarkers for gram-negative bacteria [63]. Relatively higher level of unsaturated fatty acids with low level of PUFAs supported the bacterial dominance. Relatively higher level of straight chain PLFAs was exhibited by $\mathrm{IB}_{25}$ (44.91\%) compared to different age series iron mine spoils. Branched chain PLFAs varies from $9.31 \%\left(\mathrm{IB}_{8}\right)$ to $14.53 \%\left(\mathrm{IB}_{4}\right)$. Branched chain fatty acids have been used as biomarkers for bacteria including anaerobic and sulfate-reducing bacteria. Branched chain fatty acids (iso/anteiso) are characteristic features of gram-positive bacteria, whereas cyclopropyl fatty acids are common in some gram-negative and anaerobic gram-positive bacteria [63]. The differences in relative distribution of 
branched and MUFAs are used as useful markers for the proportion of gram-positive and gram-negative bacteria $[33,57]$.

Table 2. Distribution of different PLFAs groups (\%) in the different age series iron mine overburden spoil as well as nearby NF soil.

\begin{tabular}{|c|c|c|c|c|c|c|c|c|c|}
\hline Sample & Straight & Branched & Hydroxy & MUFA & PUFA & DMA & 18:1 w9c & 18:2w6 & 10- methyl \\
\hline $\mathrm{IB}_{0}$ & 40.21 & 10.91 & 0.15 & 12.03 & 31.01 & 2.99 & 1.34 & 0.41 & 0.73 \\
\hline $\mathrm{IB}_{2}$ & 31.65 & 11.72 & 0.31 & 15.53 & 33.12 & 3.16 & 1.62 & 0.65 & 1.12 \\
\hline $\mathrm{IB}_{4}$ & 33.69 & 14.53 & 0.77 & 10.67 & 33.61 & 3.31 & 2.67 & 0.63 & 0 \\
\hline $\mathrm{IB}_{6}$ & 38.94 & 10.15 & nd & 10.54 & 32.48 & 3.52 & 3.14 & 0.78 & 0.24 \\
\hline $\mathrm{IB}_{8}$ & 43.53 & 9.31 & nd & 10.12 & 28.42 & 3.87 & 3.42 & 0.91 & 0.19 \\
\hline $\mathrm{IB}_{10}$ & 43.67 & 11.52 & nd & 10.61 & 24.94 & 3.47 & 3.96 & 1.13 & 0.31 \\
\hline $\mathrm{IB}_{25}$ & 44.91 & 11.83 & nd & 12.73 & 21.55 & 3.23 & 3.99 & 1.25 & 0.15 \\
\hline $\mathrm{NF}$ & 45.12 & 11.95 & nd & 12.85 & 20.32 & 2.75 & 4.19 & 1.98 & 0.32 \\
\hline
\end{tabular}

nd: beyond detectable limit.

Gram-negative bacteria contain unique hydroxyl fatty acids in lipopolysaccharides as cell wall composition, which act as an indicator of gram-negative bacteria in environmental samples [29, 64]. It is evident from the study that soil microbes with hydroxyl fatty acids were confined to $\operatorname{IB}_{0}(0.15 \%), \mathrm{IB}_{2}(0.31 \%)$ and $\mathrm{IB}_{4}$ $(0.77 \%)$. Higher relative abundance of methyl branching PLFAs was observed in $\mathrm{IB}_{2}(1.12 \%)$ compared to different age series iron mine spoil (Table 2). The distribution of MUFAs and PUFAs in NF soil accounted to $12.85 \%$ and $20.32 \%$ respectively (Table 2). Relatively higher level of PLFAs 18:1w9c (4.19\%) and 18:2w6c $(1.98 \%)$ representing fungi were observed in NF soil compared to different iron mine spoil. The study indicated that the differences in PLFA profiles could be attributed to the variation in lipid contributing microbial communities; environmental conditions and microbial amelioration during spontaneous succession in iron mine overburden spoil over time [65-66].

\section{Microbial community composition}

The short-term responses of microbial mediated processes and community structure to perturbation constitute important aspects of soil quality assessment and productivity. Thus, it is necessary to analyze their relative distribution or composition and microbial diversity, which provide better understanding of soil quality. Such analysis of microbial community composition has relied on the relative distribution of microbial PLFAs. Besides, PLFAs have several features that reinforce their use as indicator of environmental stress. They respond to environmental disturbances either by phenotypic plasticity or altering PLFAs composition in microbial membrane and thereby shifting microbial community structure [50]. Marked differences in microbial community composition were observed across the different age series iron mine overburden spoil over time (Table 3).

Table 3. Relative distribution of microbial communities (\%) in different age series iron mine overburden spoil as well as nearby NF soil.

\begin{tabular}{|c|c|c|c|c|c|c|c|c|}
\hline Soil sample & Gram positive & Gram negative & Anaerobes & Actinomycetes & A.M. Fungi & Fungi & Methanobacter & Eukaryote \\
\hline $\mathrm{IB}_{0}$ & 17.89 & 26.14 & 5.06 & 0.91 & 0 & 0.54 & 0.65 & 48.81 \\
\hline $\mathrm{IB}_{2}$ & 15.32 & 23.52 & 5.31 & 1.37 & 0.62 & 0.72 & 0.98 & 52.16 \\
\hline $\mathrm{IB}_{4}$ & 14.35 & 21.91 & 4.83 & 0 & 0 & 1.07 & 0 & 57.84 \\
\hline $\mathrm{IB}_{6}$ & 14.08 & 19.75 & 5.24 & 0.41 & 0 & 1.24 & 0 & 59.28 \\
\hline $\mathrm{IB}_{8}$ & 12.36 & 17.64 & 6.92 & 0.37 & 0 & 1.52 & 0 & 61.19 \\
\hline $\mathrm{IB}_{10}$ & 11.18 & 14.48 & 6.77 & 1.02 & 0.85 & 2.13 & 0 & 63.57 \\
\hline $\mathrm{IB}_{25}$ & 10.71 & 13.78 & 6.09 & 0.33 & 1.33 & 1.83 & 0 & 65.93 \\
\hline $\mathrm{NF}$ & 10.12 & 13.25 & 5.06 & 0.45 & 2.13 & 2.74 & 0 & 66.25 \\
\hline
\end{tabular}

The fresh iron mine spoil represents disequilibriated geomorphic system with altered physicochemical properties, which disrupts soil quality/stability and pedogenic processes [67]. Relatively higher level of MUFAs $[65,68]$ with lower level of PUFAs were reported as biomarkers for gram-negative bacteria [63], which explained relative abundance of gram-positive bacteria in $\mathrm{IB}_{0}(17.89 \%)$ (Table 3). The existence of hydroxyl PLFAs substantiated the higher occurrence of gram-negative bacteria in $\mathrm{IB}_{0}(26.14 \%)$ compared to different age series iron mine spoils and NF soil [29, 64]. Further, higher level of gram-positive bacteria (17.89\%) was estimated in $\mathrm{IB}_{0}$, which may be due to higher relative occurrence of branched chain fatty acids [68-69]. The study revealed higher relative dominance of gram-negative bacterial PLFAs in heavy metal contaminated mine spoil $\left(\mathrm{IB}_{0}\right)$ with concomitant decrease in gram-positive bacterial PLFAs in chronosequence iron mine spoil over time $[9,13,70]$. Higher level of DMA PLFAs indicates relatively higher distribution of anaerobes in $\mathrm{IB}_{8}$ $(6.92 \%)$ compared to different age series iron mine spoil $[13,38,42]$. The methyl-branched PLFAs represent the dominance of actinomycetes in $\operatorname{IB}_{2}(1.37 \%)[13,36,37]$, which may be due to their potentiality to withstand 
water stress by resisting plasmolysis and maintain cell turgor by accumulating compatible solutes (proline and glycerol). In addition, they are filamentous enabling them to bridge air gaps between thin water films that occur in pore spaces during soil desiccation [71]. The occurrence of relatively lower fungal PLFAs (18:1 $\omega 9 \mathrm{c}, 18: 2 \omega 6$, $18: 2 \omega 9 \mathrm{c})$ indicated minimal fungal abundance in $\mathrm{IB}_{0}(0.54 \%)$. The methanobacter population was confined to $\mathrm{IB}_{0}(0.65 \%)$ and $\mathrm{IB}_{2}(0.98 \%)$. Minimal existence of longer chain fatty acids in $\mathrm{IB}_{0}(48.81 \%)$ indicated comparatively lower input from microeukaryotes, which may be due to the interaction of heavy metals with microbial membrane proteins resulting disturbances in protein conformations and activities [9, 70, 72].

The ability to maintain microbial community composition, nutrient turnover and functioning after disturbance defines the resistance capacity of a soil subsystem. Resilience expresses the degree of response of the system impacted by disturbances and the rate of recovery in the original versus restored state of system. In addition to abiotic factors, soil microbial community composition is considered as major components of soil resilience due to their key role in nutrient cycling. Therefore, the microbial community composition in different age series iron mine overburden spoil in chronosequence over time should be compared with $\mathrm{IB}_{0}$. Comparatively higher level of MUFAs and PUFAs were detected in $\mathrm{IB}_{2}$ compared to $\mathrm{IB}_{0}$, which explained higher occurrence of gram-negative bacteria in $\mathrm{IB}_{2}(23.52 \%)[65,68]$. Besides, the relative dominance of hydroxyl PLFAs in $\mathrm{IB}_{4}$ revealed the occurrence of gram-negative bacteria in $\mathrm{IB}_{4}$ compared to different iron mine spoils (Table 3) [29, 64]. Besides, higher level of gram-positive bacteria in $\mathrm{IB}_{2}(15.32 \%)$ may be due to higher occurrence of branched chain fatty acids. Relatively lower level of anaerobes in $\operatorname{IB}_{2}(5.31 \%)$ was attributed to lower occurrence of DMA PLFAs (Table 3). Higher level of fungal PLFAs $(18: 1 \omega 9 \mathrm{c})$ revealed higher fungal dominance in $\mathrm{IB}_{2}(0.72 \%)$ compared to $\mathrm{IB}_{0}$ due to gradual establishment of vegetation and inputs of allochthonous material [73-74]. Methyl-branched PLFAs representing actinomycetes was found to be relatively higher in $\mathrm{IB}_{2}(1.37 \%)$ compared to $\mathrm{IB}_{0}(0.91 \%)$ [13, 36-37]. Distribution of methanobacter was confined to $\mathrm{IB}_{2}(0.98 \%)$ and $\mathrm{IB}_{0}(0.65 \%)$ due to the presence of 10 -methyl branched fatty acids. Further, higher occurrence of long chain fatty acids and PUFAs supported higher relative distribution of microeukaryotes in $\mathrm{IB}_{2}$ $(52.16 \%)$ compared to $\mathrm{IB}_{0}$. Thus, the recovery of resource heterogeneity and pool size following restoration progress would indicate resilience of the system leading to variation in soil microbial community composition.

PLFA profiles suggested higher level of gram-negative bacteria in $\mathrm{IB}_{4}(21.91 \%)$ and $\mathrm{IB}_{6}(19.75 \%)$ compared to $\mathrm{IB}_{8}(17.64 \%)$, which may be due to the higher level of MUFAs in $\mathrm{IB}_{4}$ and $\mathrm{IB}_{6}[63,65,68]$. Higher relative distribution of gram-negative bacteria was observed in $\operatorname{IB}_{15}(14.48 \%)$ compared to $\operatorname{IB}_{25}(13.78 \%)$. Higher distribution of gram-positive bacteria was observed in $\mathrm{IB}_{4}(14.35 \%)$ compared to $\mathrm{IB}_{6}, \mathrm{IB}_{8}, \mathrm{IB}_{15}$ and $\mathrm{IB}_{25}$, which may be due to higher occurrence of branched chain fatty acids in $\mathrm{IB}_{4}(43.53 \%)$. Lower level of anaerobes was estimated in $\mathrm{IB}_{4}(4.83 \%)$ compared to $\mathrm{IB}_{6}(5.24 \%)$, which may be due to lower occurrence of DMA PLFAs. The distribution of actinomycetes was not observed in $\mathrm{IB}_{4}$ due to absence of methyl-branched PLFAs. Methylbranched PLFAs was found to be higher in $\mathrm{IB}_{15}(1.02 \%)$ compared to $\mathrm{IB}_{25}(0.33 \%)$. Higher level of fungal PLFAs $(18: 1 \omega 9 \mathrm{c})$ revealed higher fungal dominance in $\mathrm{IB}_{15}(2.15 \%)$ compared to different age series mine spoils. Higher relative distribution of PLFA 16:1 $155 \mathrm{c}$ reflects the dominance of arbuscular mycorrhizal fungi in $\mathrm{IB}_{25}(1.33 \%)$ compared to $\mathrm{IB}_{15}(0.85 \%)$ and $\mathrm{IB}_{2}(0.62 \%)$. However, the distribution of arbuscular mycorrhizal fungi was not observed in $\mathrm{IB}_{0}, \mathrm{IB}_{4}, \mathrm{IB}_{6}$ and $\mathrm{IB}_{8}$. Higher longer chain fatty acids indicate relatively higher inputs from microeukaryotes in $\mathrm{IB}_{25}(65.93 \%)$ compared to different iron mine spoils.

The distribution of gram-positive, gram-negative, anaerobes and actinomycetes in NF soil was found to be $10.12 \%, 13.25 \%, 5.06 \%$ and $0.45 \%$ respectively (Table 3 ). Relative abundance of gram-negative as compared to gram-positive bacteria in NF soil indicated profound effect of vegetation on mine spoil genesis and lipid profile. Higher relative distribution of arbuscular mycorrhizal fungi $(2.13 \%)$, fungi $(2.74 \%)$ and microeukaryotes $(66.25 \%)$ were observed in NF soil, which may be due to allochthonous inputs, root turnover and symbiotic nitrogen fixation contributed to formation of highly localized soil resources characterized by higher level of organic $\mathrm{C}$ and $\mathrm{N}$ that are believed to support more diverse heterotrophic microbial population. Greater PLFA diversity also concurred with studies on vegetation succession [75-76]. Further, fungi are adapted to degrade lignin and formation of organic matter [61]. Comparative analysis based on the distribution of PLFAs suggested that the heavy metal contamination in mine spoil resulted decline in PLFAs (a15:0, 16:1 $155 \mathrm{c}$,

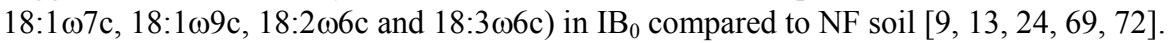

Further, PLFA markers were used to quantify the relative abundance of gram-positive (i14:0, i15:0, a15:0, i16:0, 10Me16:0, i17:0, a17:0, 10Me17:0) to gram-negative bacteria $(15: 1 \omega 4 \mathrm{c}, 16: 1 \omega 7 \mathrm{c}, 16: 1 \omega 9 \mathrm{c}$,

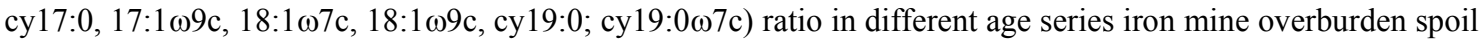
and NF soil $[27,42,62,77]$. The ratio of gram-positive to gram-negative bacteria exhibited a decline trend from $\mathrm{IB}_{0}(2.129)$ to $\mathrm{IB}_{25}(1.137)$ and was found to be minimum in NF soil (1.104) compared to different iron mine overburden spoil (Figure 2). Such increase in gram-negative bacteria may be attributed to gradual improvement in organic $\mathrm{C}$ supported by vegetation development in chronosequence iron mine overburden spoil over time [67], which provides more stable and readily available substrate for supporting higher microbial activity of gram-negative bacteria [78]. Several investigations have suggested that the gram-negative bacteria were closely associated with MUFAs, which correspond to the gradual increase in organic matter and high substrate 
availability $[58,79]$. Thus, the combined effect contributed by the changes in aboveground and belowground inputs would influence the microbial community structure by altering $\mathrm{C}$ inputs from root exudates and litter in chronosequence iron mine overburden spoil influencing the pace and progress of mine spoil restoration over time $[19,35,66]$.

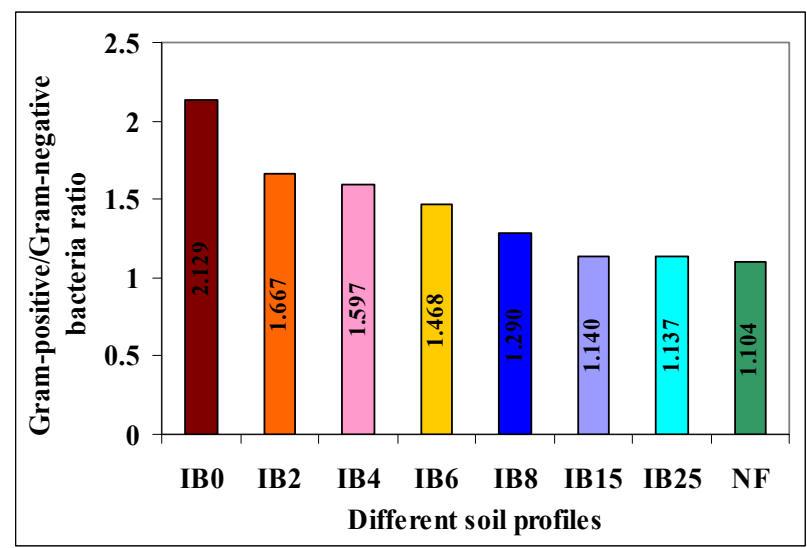

Figure 2. Gram-positive to gram-negative bacteria ratio in the different age series iron mine overburden spoil ( $\left.\mathrm{IB}_{0} \rightarrow \mathrm{IB}_{25}\right)$ as well as nearby NF soil across the sites.

\section{Shannon-weaver diversity index}

The numerical strength and biomass of microorganisms affect ecosystem functioning. Microorganisms can change, modify and regulate microenvironment through their activities. Thus, the periodic assessment of microbial community structure with space and time is pre-requisite so as to understand their role in ecosystem stability and development. In addition, the ability of an ecosystem to withstand extremities may contribute to variation in microbial community structure and hence microbial diversity. The commonly used form of diversity index is Shannon Weaver index $(\mathrm{H})$, which is frequently used in microbial ecology studies. Diversity index is a quantitative measure that not only accounts the existence of PLFAs richness (R) but also accounts how evenly they are distributed (evenness). Total diversity depends upon (a) the number of species or number of parts (variety component), (b) the evenness component or the distribution of relative abundance. Higher overall diversity occurs when the number of species and the evenness component are larger. The bacterial and fungal PLFAs are mostly used as the measure of relative distribution of different microbial groups based on their relative abundance of certain PLFAs [20], which differ considerably among different microbial groups [58]. The study revealed significant variation in PLFA richness, Shannon diversity index and evenness in different age series iron mine overburden spoil and nearby NF soil (Table 4).

Table 4. Shannon diversity index and Pielou's evenness index based on the distribution of 75 PLFAs in the seven different age series iron mine overburden spoil $\left(\mathrm{IB}_{0} \rightarrow \mathrm{IB}_{25}\right)$ as well as NF soil across the sites.

\begin{tabular}{|c|c|c|c|}
\hline Site & PLFA richness $(R)$ & Shannon diversity index $(H)$ & Pielou's evenness index $(J)$ \\
\hline $\mathrm{IB}_{0}$ & 49 & 2.726231353 & 0.700502887 \\
\hline $\mathrm{IB}_{2}$ & 47 & 2.849070813 & 0.739990023 \\
\hline $\mathrm{IB}_{4}$ & 27 & 2.490509005 & 0.755652997 \\
\hline $\mathrm{IB}_{6}$ & 43 & 2.717641045 & 0.722546252 \\
\hline $\mathrm{IB}_{8}$ & 49 & 2.794246578 & 0.717979342 \\
\hline $\mathrm{IB}_{15}$ & 49 & 2.783612478 & 0.715246919 \\
\hline $\mathrm{IB}_{25}$ & 48 & 2.74195037 & 0.708294496 \\
\hline $\mathrm{NF}$ & 43 & 3.17054272 & 0.842960391 \\
\hline
\end{tabular}

Greater PLFA richness (R) was attributed by $\mathrm{IB}_{0} \mathrm{IB}_{8}$ and $\mathrm{IB}_{8}(49)$ compared to other mine spoil profiles. Shannon diversity index $(\mathrm{H})$ varies from $2.4905\left(\mathrm{IB}_{4}\right)$ to $2.8490\left(\mathrm{IB}_{2}\right)$ across the sites. The relative abundance of evenness is the apportionment of individuals among the species is an important component of diversity index, which quantifies how equal the community is numerically. It would be useful to assess the contribution of this component to the diverse index value. The evenness of PLFA reflects the broad-scale changes in terms of the relative dominance of certain microbial groups although an evenness index should be independent of the number of species [50]. The evenness of community otherwise called Pielous evenness index (J) is constrained between 0 and 1 represents the ratio of observed heterogeneity to maximum possible heterogeneity. The Pielous evenness index $(\mathrm{J})$ based on the distribution of 75 PLFAs varies from $0.7005\left(\mathrm{IB}_{0}\right)$ to $0.7556\left(\mathrm{IB}_{4}\right)$ across the sites (Table 4). The more even the distribution of PLFAs or less variation in community between microbial groups, greater is 
the microbial diversity. Thus, the value of diversity index increases when both the number of types of PLFAs and evenness increases.

Shannon diversity index based on the distribution of different microbial groups in different iron mine overburden spoil and NF soil was calculated. Higher Shannon Weaver index in $\operatorname{IB}_{2}(1.2943)$ revealed higher population diversity compared to $\mathrm{IB}_{0}(1.2633)$. Comparatively higher level of microbial diversity was exhibited by $\mathrm{IB}_{6}(1.1378)$ than $\mathrm{IB}_{4}(1.1228)$. Higher level of microbial diversity was exhibited by $\mathrm{IB}_{15}(1.1643)$ compared to $\mathrm{IB}_{8}(1.1341)$. However, $\mathrm{IB}_{25}(1.1069)$ exhibited relatively lower microbial diversity compared to $\mathrm{IB}_{8}$ and $\mathrm{IB}_{15}$, which indicated that the microbial communities in less disturbed ecosystem like $\mathrm{IB}_{25}$ may be dynamic in terms of functional responses to perturbation but more resistance to changes in microbial community composition [56]. The shift in microbial community structure and diversity among different iron mine overburden spoil may be attributed to the variation in microbial biomass nutrient to soil nutrients ratio (MB-C:OC), which represents the quantum of soil nutrients reflected in microbial biomass and used as functional index of the soil subsystem [80].

\section{E. Fungal: bacterial biomass ratio}

Fungal biomass was calculated based on the relative distribution of PLFA 18:2 $\omega 6 \mathrm{c}$ across the sites. Total bacterial biomass was obtained by summation of the distribution of PLFAs 14:0, 15:0, a15:0, i15:0, i16:0,

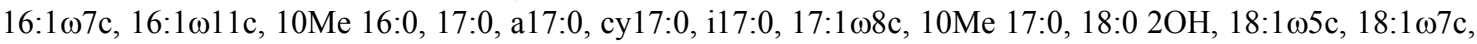
$10 \mathrm{Me} 18: 0,19: 1 \omega 6 \mathrm{c}$ and cy 19:0 $\omega 8 \mathrm{c}$. An index of fungal to bacterial $(\mathrm{F} / \mathrm{B})$ ratio of microbial biomass was used to study the state of microbial community in response to different environmental stresses [50]. The F:B ratio was suggested as the potential tool to discriminate the disturbed from undisturbed soil system [20, 71, 81]. The fundamental difference in bacterial/fungal physiology and ecology would suggest that the biogeography of each group would be influenced by different edaphic factors, which may vary among different soil profiles [82]. The bacteria and fungi are likely to have distinct functional roles in different mine spoil profiles and therefore more robust understanding of the site-specific effects of land use patterns and edaphic factors on these microbial population will improve the ability to predict changes in microbial community composition and function [50]. The $F: B$ ratio exhibited an increasing trend from $\operatorname{IB}_{0}(0.0233)$ to $\mathrm{IB}_{25}(0.0640)$ over time. Comparatively higher $\mathrm{F}: \mathrm{B}$ ratio was estimated in $\mathrm{IB}_{25}(0.0640)$ compared to $\mathrm{IB}_{2}(0.0263), \mathrm{IB}_{4}(0.0362), \mathrm{IB}_{6}(0.0405), \mathrm{IB}_{8}(0.0485)$ and $\mathrm{IB}_{15}$ (0.0538). However, the difference in $\mathrm{F}: \mathrm{B}$ ratio in chronosequence iron mine overburden spoil was less pronounced due to heavy metal contaminated extreme environmental conditions [13, 24, 70]. Highest F:B ratio was observed in NF soil (0.1116) compared to different age series iron mine overburden spoil, which may be due to higher prevalence of fungal PLFAs exhibiting higher $\mathrm{C}: \mathrm{N}$ ratio and low bulk density [83]. The bacterial PLFAs increased considerably with the increase in $\mathrm{pH}$ and were found to be higher in NF soil [84]. However, fungal biomass is higher in acid soil with high $\mathrm{C}: \mathrm{N}$ ratio indicating that $\mathrm{pH}$ appears to be the most important factor for microbial abundance, diversity and activities [55, 84-85]. In fact, soil $\mathrm{pH}$ affects microbial processes such as organic matter mineralization, which is slowed down or even stopped at higher acidic or alkaline $\mathrm{pH}$ [86-87]. Besides, the shift in microbial community may also be related to the capacity of fungi for translocation $\mathrm{N}$ to $\mathrm{C}$ availability or direct influence of $\mathrm{N}$ supply on plant belowground $\mathrm{C}$ allocation is thought to be important in NF soil with higher C:N ratio [81, 84]. Several investigations have suggested that the level of activity and size of microbial communities are $\mathrm{C}$ limited [88]. Further, higher F:B ratio in NF soil can be explained on the basis of the existence of higher relative distribution fungal PLFAs $(2.74 \%)$ compared to different iron mine overburden spoil. In addition, NF soil was supported with distinct microbial communities that can be correlated with factors that define the land-use pattern and associated soil quality influencing microbial community composition [56]. It is evident that NF soil appeared to be set apart from other mine spoil profiles with higher abundance of arbuscular mycorrhizal fungi $(2.13 \%)$, which may be better able to cope with available $\mathrm{N}$ and organic matter. These parameters show linear increase with increased abandonment duration consistent with fungal to bacterial ratio [81, 84, 89-90]. The study indicated that the disturbed ecosystems have lower F:B ratio whereas organically managed soil have increased F:B ratio than conventional system [91].

Further, the changes in microbial community structure may be influenced by spatial variability in soil physicochemical properties ( $\mathrm{pH}$, moisture and nutrient availability), which influence microbial transformations altering nutrient cycling useful in providing insight how these microbes could affect the soil quality status. Differences in soil $\mathrm{pH}$ can arise due to the variation in vegetation pattern and management regimes. Thus, soil $\mathrm{pH}$ serves as one of the integrating variables and reasonably good predictor of microbial community composition [92-93]. The decline in soil $\mathrm{pH}$ from $\mathrm{NF}$ soil to $\mathrm{IB}_{0}$ may be one of the major constraints/stresses that shift the microbial community structure $[51,67]$. Comparative analysis of $\mathrm{F}: \mathrm{B}$ ratio suggested that lower $\mathrm{pH}$

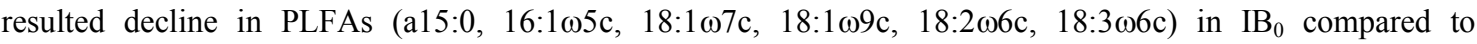
undisturbed NF soil [55]. The decreased stress with gradual improvement in soil $\mathrm{pH}$ towards neutral in NF soil in chronosequence iron mine overburden spoil could be related to an increase in $\mathrm{F}: \mathrm{B}$ ratio due to nutrient availability leading to the shift in microbial community structure [55, 67, 84, 94-95]. The study revealed positive correlation between $\mathrm{F}: \mathrm{B}$ ratio and soil $\mathrm{pH}(\mathrm{r}=0.966, p<0.001)$, which suggested that soil $\mathrm{pH}$ can 
account $93.47 \%$ of the variability in F:B ratio (Figure $3 \mathrm{a}$ ). Besides, the shift in microbial community as well as $\mathrm{F}: \mathrm{B}$ ratio may be due to variation in moisture content from $\mathrm{IB}_{0}$ to $\mathrm{NF}$ soil, which influence osmotic potential, transport of nutrients regulating microbial mediated processes and competitive interactions between microbial species [66, 96-97]. Soil moisture content exhibited positive correlation with $\mathrm{F}: \mathrm{B}$ ratio $(\mathrm{r}=0.784, p<0.001)$, which can account $61.48 \%$ of the variability in $F: B$ ratio across the sites (Figure $3 \mathrm{~b}$ ). The changes in moisture content can alter microbial community composition and function due to differences in drought tolerance among taxonomic and functional groups of soil microorganisms [98-99].

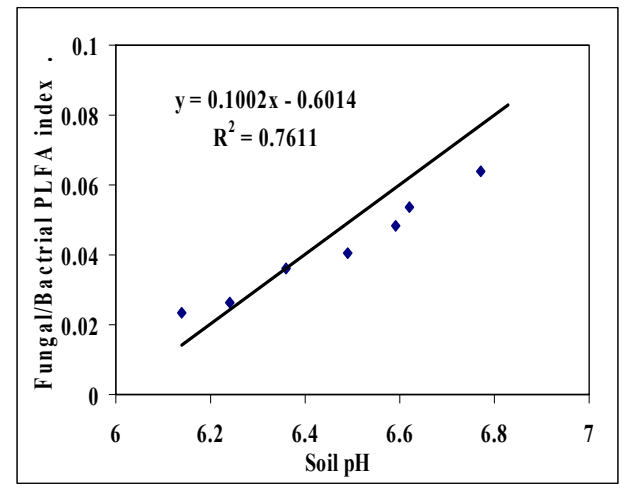

(a)

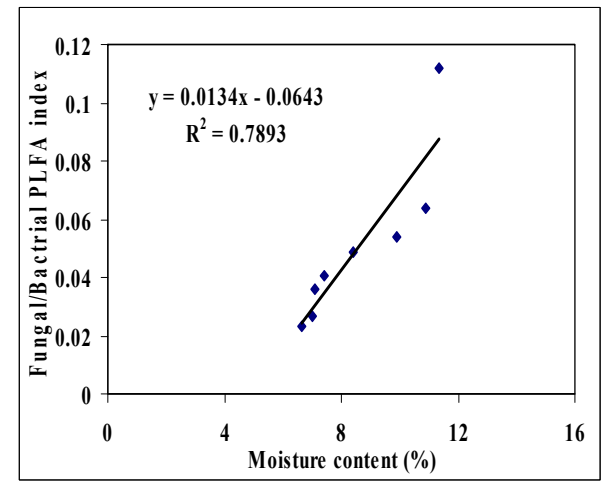

(b)

Figure 3. Correlation between fungal to bacterial ratio with (a) soil pH and (b) moisture content in the different age series

\section{F. Cluster analysis} iron mine overburden spoil and NF soil.

Relative distributions of 75 PLFAs among different age series iron mine spoil and NF soil profiles were subjected to cluster analysis based on distance matrix revealed the existence of seven clusters (I-VII) (Figure 4). The dendrogram revealed highest similarity (71.8998) between $\mathrm{IB}_{0}$ and $\mathrm{IB}_{6}$ (cluster VII). The relatedness between $\mathrm{IB}_{0}$ and $\mathrm{IB}_{8}$ (cluster-VI), $\mathrm{IB}_{0}$ and $\mathrm{IB}_{15}$ (cluster-V) and $\mathrm{IB}_{0}$ and $\mathrm{IB}_{2}$ (cluster-IV) exhibited similarity level 67.1458, 56.7162 and 52.6909 respectively. The similarity level between $\mathrm{IB}_{4}$ and $\mathrm{IB}_{25}$ was estimated to be 49.0519 (cluster-III). IB $_{0}$ and IB $_{4}$ exhibited similarity level (48.3590) representing cluster-II. Minimal similarity level (34.7702) was observed between $\mathrm{IB}_{0}$ and NF (cluster-I). The study indicated that the seven clusters based on relative distribution of 75 PLFAs exhibited the tree likeness of original (unrandomized) tree was statistically well resolved (Figure 4).

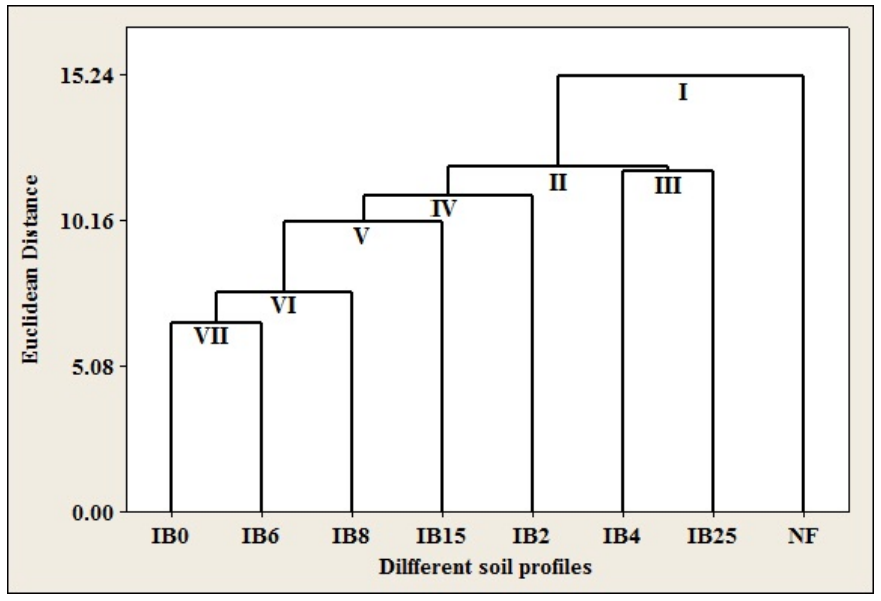

Figure 4. Cluster analyses illustrated the relatedness based on the relative distribution of 75 PLFAs among different age series iron mine overburden spoil as well as NF soil.

Further, principal component analysis was performed in order to discriminate seven different age series iron mine overburden spoil and nearby NF soil based on the relative distribution of 75 PLFAs across the sites (Figure 5) [100]. Eigen vectors determine the direction of maximum variability specifying the variances. Principal component analysis suggested that the $\mathrm{Z} 1$ and $\mathrm{Z} 2$ components explained maximum variance with their cumulative percentage of variance estimated to be $58.57 \%$. The relative distribution of 75 PLFAs revealed differential microbial community structure among seven different age series iron mine overburden spoil in chronosequence and nearby NF soil were well segregated (Figure 5). 


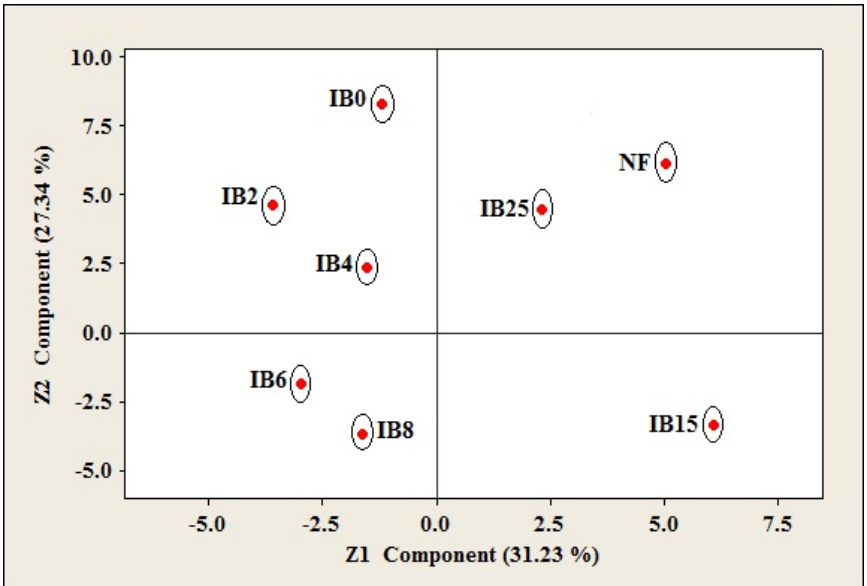

Figure 5. Principal component analysis based on the relative distribution of 75 PLFAs among the microbial communities in different mine overburden spoil as well as NF soil.

\section{G. Multivariate analyses}

Redundancy analysis was used to examine the patterns in PLFA data collected from different age series iron mine overburden spoil reflecting relationship between different mine spoil profiles, species and environmental gradients altogether. The changes in microbial community structure may occur in response to altered physico-chemical properties that affect the soil microenvironment with possible effects on the efficiency of readily mineralizable resource conservation by soil microbes. RDA analysis allowed examining the variation in PLFA patterns in terms of both iron mine overburden sites and the measured environmental gradients including enzyme activities, which was found to be significant $(p<0.005)$. A total of $61.62 \%$ of the variability could be explained based on the fitted PLFA data by the model from the canonical sum of eigen values. Seven different age series iron mine overburden sites and environmental gradient arrows for the RDA ordination of PLFA data were shown (Figure 6a). The slit and clay \%, moisture content (MC), water holding capacity (WHC), $\mathrm{pH}$, organic $\mathrm{C}(\mathrm{OC})$, total $\mathrm{N}(\mathrm{TN})$, extractable $\mathrm{P}(\mathrm{EP})$ and enzyme activity (amylase, invertase, protease, urease and dehydrogenase) increased in the general direction of $\mathrm{IB}_{25}$, while sand \% and bulk density (BD) increased towards $\mathrm{IB}_{0}$. The increasing trend of these parameters correspond to enhance accumulation of organic $\mathrm{C}$, available $\mathrm{N}$ and microbial community composition as vegetation succession proceeded over time reflecting the sign of mine spoil restoration [101-103].

The data related to physico-chemical properties and enzyme activities in chronosequence iron mine overburden spoil were taken for RDA analysis [67, 83]. The proportions of certain PLFAs were highly correlated with physico-chemical properties (Jackson et al., 2003) in different iron mine overburden spoil over time (Figure 6b). The clay, pH, MC, WHC, OC, TN, EP and enzyme activities were highly correlated with

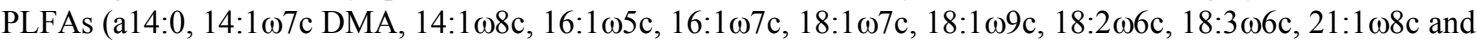

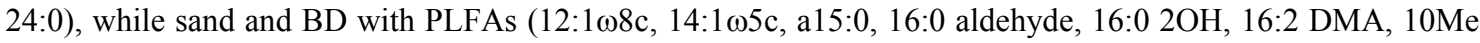

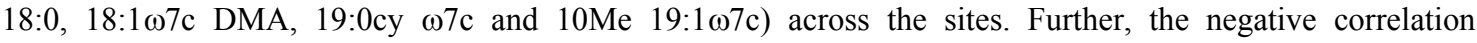
coefficients indicated that the changes in microbial community structure in response to disturbances were associated with the decrease in respective soil properties in different mine spoil profiles. Although 75 PLFAs were included in RDA ordination, but the PLFAs with highest species scores in the first two ordination axes, which correlated well with environmental variables and important biological markers are displayed for clarity (Figure 6b). Some general patterns emerge from this analysis. The existence of higher level of methyl-branched PLFAs (10Me16:0; 10Me22:0) and saturated branched fatty acids $\left(\mathrm{C}_{16}\right.$ to $\left.\mathrm{C}_{19}\right)$ in $\mathrm{IB}_{0}$ suggested higher relative abundance of actinomycetes and anaerobic bacteria respectively. In addition, higher pyrite $\left(\mathrm{FeS}_{2}\right)$ contamination provides suitable condition for the existence of PLFA a17:0 reflecting higher distribution of sulfate reducing bacteria in $\mathrm{IB}_{0}$. Further, the level of saturated branched fatty acids $\left(\mathrm{C}_{14}\right.$ to $\left.\mathrm{C}_{16}\right)$ was found to be comparatively higher in $\mathrm{IB}_{10}$ than different age series iron mine overburden spoil suggesting higher relative abundance of gram-positive bacteria in $\mathrm{IB}_{10}$. Minimal longer chain PLFAs in $\mathrm{IB}_{0}$ indicated comparatively lower input from microeukaryotes, which may be influenced by acidic $\mathrm{pH}$ and induced toxic metal contamination [57, 94, 105]. Higher relative abundance of arbuscular mycorrhizal fungi $(16: 1 \omega 5 \mathrm{c})$ and heterotrophic microeukaryotes were

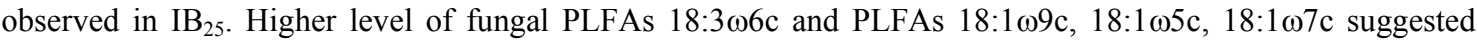
higher relative distribution of fungal population in $\mathrm{IB}_{25}$ and $\mathrm{IB}_{15}$ respectively. Besides, higher level of PLFAs $16: 1 \omega 5 \mathrm{c}$ and $16: 1 \omega 7 \mathrm{c}$ suggested higher relative distribution of aerobic bacteria in $\mathrm{IB}_{25}$ and $\mathrm{IB}_{15}$ respectively. The study suggested that the shift in microbial community structure from $\mathrm{IB}_{0}$ to $\mathrm{IB}_{25}$ may be attributed to the change in soil quality in the direction of $\mathrm{IB}_{25}$ supplementing the mine spoil restoration over time. 

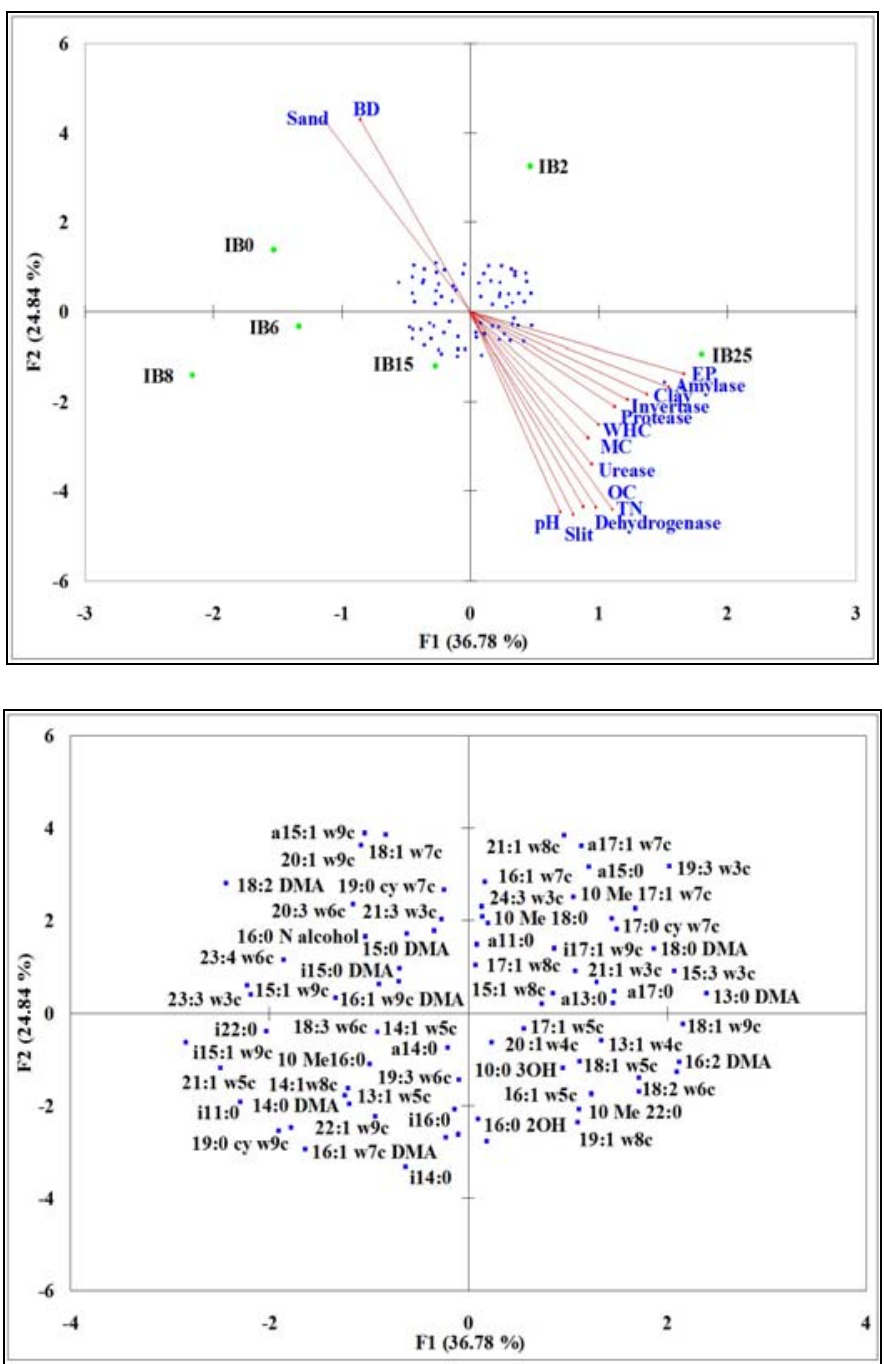

Figure 6. Redundancy analyses (RDA) of the PLFA data set for seven different age series iron mine overburden spoil, using 75 PLFAs and 11 environmental variables. (a) Site codes for each soil sample; (b) showed the PLFAs that had the highest absolute species scores on each of the two axes, along with additional PLFAs of biological interest.

\section{CONCLUSION}

The changes in microbial community structure not only ascertain the microbial diversity, but also the function and nature of interactions among existing microbial species as well as the physiological state of ecosystem. A realistic ecological assessment of iron mine spoil restoration implies periodic monitoring. The presence and abundance of these signature fatty acids in mine spoil revealed the presence and abundance of a particular microbe or groups of microbes. PLFA analysis can be used for comparative assessment of physiological status of microbial communities in different mine spoil profiles. The multivariate analysis revealed that seven different age series iron mine overburden spoil had distinctly different PLFAs and microbial community composition. The spatial and statistical results of PLFA analysis revealed the pace or rapidity of alteration in microbial community structure. Further, the changes in microbial community composition may occur in response to altered physico-chemical properties with possible effects on the efficiency of $\mathrm{C}$ conservation mediated by soil microorganisms. Nevertheless, the readily mineralizable source of organic matter would enhance microbial processes including enzyme activities to change microenvironment. PCA revealed that the microbial communities were compositionally distinct. Thus, PLFA profiling provides a sensitive and meaningful measure of microbial community composition to monitor mine spoil restoration based on soil quality assessment in chronosequence iron mine overburden spoil over time compared to undisturbed NF soil.

\section{ACKNOWLEDGEMENTS}

The authors are thankful to Head, School of life Sciences, Sambalpur University for providing laboratory facilities. The investigation was made possible through the support rendered by the mining authority 
by providing necessary facilities during sampling in the field. In particular, the authors are indebted to many, who helped in the laboratory as well as for computation of statistical analysis.

\section{REFERENCES}

[1] K. L. Steenwerth, L. E. Jackson, F. J. Calderon, M. R. Stromberg and K. M. Scow. "Soil microbial community composition and land use history in cultivated and grassland ecosystems of coastal California”, Soil Biol Biochem, vol. 34, pp. 1599-1611, 2002.

[2] D. Edmeades. "The long-term effects of manures and fertilisers on soil productivity and quality: a review", Nutr Cycl Agroecosyst, vol. 66, pp. 165-180, 2003.

[3] J. Harris. "Soil microbial communities and restoration ecology: facilitators or followers?" Sci, vol. 325, pp. 573-574, 2009.

[4] M. Kujur, A. K. Patel. "PLFA Profiling of soil microbial community structure and diversity in different dry tropical ecosystems of Jharkhand", Int J Curr Microbiol Appl Sci, vol. 3(3), pp. 556-575, 2014.

[5] E. Hackl, G. Bachmann and S. Zechmeister-Bolternstern. "Microbial nitrogen turnover in soils under different types of natural forest", Forest Ecol Manage, vol. 188, pp. 101-112, 2004.

[6] P. Garbeva, J. A. van Veen, J. D and van Elsas. "Predominant Bacillus spp. in agricultural soil under different management regimes detected via PCR-DGGE", Microb Ecol, vol. 45, pp. 302-316, 2003.

[7] A. Tunlid and C. White. "Biochemical analysis of biomass, community structure, nutritional status and metabolic activity of microbial communities in soil. In: Soil Biochemistry (eds). Bollag JM, Stotzky G, Dekker M, pp. 229-262, 1992.

[8] L. Zelles, Q. Y. Bai, T. Beck and F. Beese. "Signature fatty acids in phospholipids and lipopolysaccharides as indicators of microbial biomass and community structure in agricultural soils", Soil Biol Biochem, vol. 24, pp. 317-323, 1992.

[9] A. Frostegard, E. Baath and A. Tunlip. "Shifts in the structure of soil microbial communities in limed soils as revealed by phospholipid fatty acid analysis", Soil Biol Biochem, vol. 25, pp. 723-730, 1993.

[10] E. Baath, M. Diaz-Ravina and L. R. Bakken. "Microbial biomass, community structure and metal tolerance of a naturally Pb-enriched forest soil”, Microb Ecol, vol. 50, pp. 496-505, 2005.

[11] R. E. Drenovsky, K. L. Steenwerth, L. E. Jackson, K. M. Scow. "Land use and climatic factors structure regional patterns in soil microbial communities", Glob Ecol Biogeogr, vol. 19, pp. 27-39, 2010.

[12] T. Pennanen, J. Liski, E. Baath, V. Kitunen, J. Uotila, C. J. Westman and H, Fritze. "Structure of the microbial communities in coniferous forest soils in relation to site fertility and stand development stage", Microb Ecol, vol. 38, pp. 168-179, 1999.

[13] L. Zelles. "Fatty acid patterns of phospholipids and lipopolysaccharides in the characterization of microbial communities in soil: A review", Biol Fertil Soils, vol. 29, pp. 111-129, 1999.

[14] K. M. Batten, K. M. Scow, K. F. Davies and S. P. Harrison. "Two invasive plants alter soil microbial community composition in serpentine grasslands", Biol Invasions, vol. 8, pp. 217-230, 2006.

[15] D. B. Hedrick, A. Peacock, J. R. Stephan, S. J. Macnaughton, J. Bruggemann and D. C. White. "Measuring microbial community diversity using polar lipid fatty acid and denaturing gradient gel electrophoresis data", J Microbiol Methods, vol. 41, pp. 235-248, 2000.

[16] H. Yao, Z. He, M. J. Wilson and C. D. Campbell. "Microbial biomass and community structure in a sequence of soils with increasing fertility and changing land use", Micro Ecol, vol. 40, pp. 223-237, 2000.

[17] J. A. Harris. "Measurements of the soil microbial community for estimating the success of restoration", Eur J Soil Sci, vol. 54, pp. 801-808, 2003.

[18] D. C. White, W. M. Davies, J. S. Nickels, J. D. King, R. J. Bobbie. "Determination of the sedimentary microbial biomass by extractable lipid phosphate", Oecologia, vol. 40, pp. 51-62, 1979.

[19] X. Lie, L. Guo-bin, X. Sha and Z. Chao. "Soil microbial composition during natural recovery in the Loess plateau", China J Intergrat Agri, vol. 13, pp. 1-18, 2013.

[20] R. D. Bardgett and E. McAlister. "The measurement of soil fungal:bacterial biomass ratios as an indicator of ecosystem selfregulation in temperate meadow grasslands", Biol Fertil Soils, vol. 29, pp. 282-290, 1999.

[21] F. J. Calderon, L. E. Jackson, K. M. Scow and D. E. Rolston. "Microbial responses to simulated tillage in cultivated and uncultivated soils". Soil Biol Biochem, vol. 32, pp. 1547-1559, 2000.

[22] R. E. Drenovsky, G. N. Elliott, K. J. Graham and K. M. Scow. ”Comparison of phospholipid fatty acid (PLFA) and total soil fatty acid methyl esters (TSFAME) for characterizing soil microbial communities”, Soil Biol Biochem, vol. 36, pp. 1793-1800, 2004.

[23] Y. P. Wu, B. Ma, L. Zhou, H. Z. Wang, J. M. Xu, S. Kemmitt and P. C. Brookes. "Changes in the soil microbial community structure with latitude in eastern China, based on phospholipid fatty acid analysis", Appl Soil Ecol, vol. 43, pp. 234-240, 2009.

[24] T. Pennanen, A. S. A. Frostegard, H. Fritze, E. Baath. "Phospholipid fatty acid composition and heavy metal tolerance of soil microbial communities along two heavy metal-polluted gradients in coniferous forests", Appl Environ Microbiol, vol. 62(2), pp. 420428, 1996.

[25] A. Frostegard, A. Tunlid and E. Baath. "Use and misuse of PLFA measurements in soil", Soil Biol Biochm, vol. 43(8), pp. 1621-1625, 2011.

[26] J. R. Vestal, D. C. White. "Lipid analysis in microbial ecology quantitative approaches to the study of microbial communities", Biosci, vol. 39, pp. 535-541, 1989.

[27] D. C. White, J. O. Stair, D. B. Ringelberg. "Quantitative comparisons of in situ microbial biodiversity by signature biomarker analysis", J Ind Microbiol, vol. 17, pp. 185-196, 1996.

[28] J. Steer and J. A. Harris. "Shift in the microbial community in the rhizosphere and non rhizosphere soils during the growth of Agrostis stolonifera”, Soil Biol Biochem, vol. 32, pp. 869-878, 2000. 
[29] D. C. White. "Is there anything else you to understand about the microbiota that cannot be derived from analysis of nucleic acid?", Microbiol Ecol, vol. 28, pp. 163-166, 1994.

[30] M. Diaz-Ravina, E. Baath, A. Martin and T. Carballas. "Microbial community structure in forest soils treated with a fire retardant", Biol Fertil Soils, vol. 42, pp. 465-471, 2006.

[31] M, Lores, M. Gomez-Brandon and J. Dominguez. "Tracking down microbial communities via fatty acid and analysis: Analytical strategy for solid organic samples", Curr resear, technology and education topics in applied microbiology and microbial biotechnology (eds), Mendez-Vilas A, pp. 1502-1508, 2010.

[32] S. J. M. Dickens, E. B. Allen, L. S. Santiago and D. Crowley. "Exotic annuals reduce soil heterogeneity in coastal sage scrub soil chemical and biological characteristics". Soil Biol Biochem, vol. 58, pp. 70-81, 2013.

[33] J. A. W. Morgan and C. Winstanley. "Microbial biomarkers. In: Modern soil microbiology (eds)". J. D. van Elsas, J. T. Trevors, E. M. H. Wellington, M. Dekker. Inc., New York, pp. 331-348, 1997.

[34] A. Frostegard and E. Baath. "The use of phospholipid fatty acid to estimate bacterial and fungal biomass in soil", Biol Fertil Soils, vol. 22, pp. 59-65, 1996.

[35] R. T. Myers, D. R. Zak, D. C. White, A. Peacock. "Landscape-level patterns of microbial community composition and substrate use in upland forest ecosystems", Soil Sci Soc Am J, vol. 65, pp. 359-367, 2001

[36] M. Kroppenstedt. "Fatty acid and menaquinon analysis of actinomycetes and related organisms In: Chemical methods in bacterial systematics (eds) Googfellow M, Minnikin DE”, Academic Press, London, pp. 173-199, 1985.

[37] G. T. Hill, N. A. Mitkowski, L. Aldrich-Wolfe, L. R. Emele, D. D. Jurkonie, A. Ficke, S. Maldonado-Ramirez, S. T. Lynch and E. B. Nelson. "Methods for assessing the composition and diversity of soil microbial communities", Appl Soil Ecol, vol. 15, pp. 25-36, 2000.

[38] A. Frostegard, A. Tunlid and E. Baath. "Microbial biomass measured as total lipid phosphate in soils of different organic content", $J$ Microbiol Method, vol. 14, pp. 151-163, 1991.

[39] S. Zhong, Y. Wu and J. Xu. "Phosphorus utilization and microbial community in response to lead/iron addition to a waterlogged soil", J Environ Sci, vol. 21, pp. 1415-1423, 2009.

[40] J. P. Bowman, J. H. Skerratt, P. D. Nicholas and L. I. Sly. "Phospholipid fatty acid and lipopolysaccharide fatty acid signature lipids in methane utilizing bacteria". FEMS Microb Ecol, vol. 85, pp. 15-22, 1991.

[41] J. V. Robie and D. C. White. "Lipid analysis in microbial ecology: Quantitative approaches to the study of microbial communities", Biosci, vol. 39(8), pp. 535-541, 1989.

[42] L. Zelles. "Phospholipid fatty acid profiles in selected members for soil microbial communities", Chemosphere, vol. 35, pp. 275-294, 1997.

[43] H. C. Pinkart, D. B. Ringelberg, Y. M. Piceno, S. J. Macnaughton and D. C. White. "Biochemical approaches to biomass measurements and community structure analysis”, In: C. J. Hurst, R. L. Crawford, G. R. Knudsen, M. J. McInerney, L. D. Stetzenbach, editors. Manual of environmental microbiology. 2. Am Soc Microbiol. Press; Washington, DC, pp.101-113, 1999.

[44] A. Frostegard, A. Tunlid and E. Baath. "Use and misuse of PLFA measurements in soils". Soil Biol Biochem, pp. 1-5, 2010.

[45] M. A. Arshad and S. Martin. "Identifying critical limits for soil quality indicators in agro ecosystems", Agri Ecosys Environ, vol. 88, pp. 153-160, 2002.

[46] G. Renella, L. Landi, J. Ascher, M. T. Ceccherini, G. Pietramellara, M. Mench, P. Nannipieri. "Long-term effects of aided phytostabilisation of trace elements on microbial biomass and activity, enzyme activities, and composition of microbial community in the Jales contaminated mine spoils", Environ Pollution, vol. 152, pp. 702-712, 2008.

[47] N. Chowdhury, P. Marschner and R. Burns. "Response of microbial activity and community structure to decreasing soil osmotic and metric potential”, Plant Soil, vol. 344, pp. 241-254, 2011.

[48] S. D. Veresoglou, A. P. Mamolos, B. Thornton, O. K. Voulgari, R. Sen, D. S. Vereogou. "Medium-term fertilization of grassland plant communities masks plant species-linked effects on soil microbial community structure", Plant Soil, vol. 344, pp. 187-196, 2011.

[49] A. Halbritter and T. Mogyorossy. "Phospholipid fatty acid analysis of rhizosphere bacterial communities in a peat soil", Agrokemiaes Talaj Tan, vol. 51(2), pp. 123-128, 2002.

[50] A. Kaur, R. Choudhary and R. Kaushik. "Phospholipid fatty acid: A bioindicator of environment monitoring assessment in soil ecosystem", Curr Sci, vol. 89, pp. 1103-1112, 2005.

[51] E. Hackl, M. Pfeffer, C. Donat, G. Bachmann and S. Zechmeister-Boltenstern. "Composition of the microbial communities in the mineral soil under different types of natural forest”, Soil Biol Biochem, vol. 37, pp. 661-671, 2005.

[52] D. Parkinson, T.R.G. Gray, S. T. Williams. "Methods to study ecology of soil microorganisms", IBP Handbook No.19. Oxford, Blackwell Scientific Publishing, pp. 116, 1971.

[53] J. S. Buyer, J. R. Teasdale, D. P. Roberts, I. A. Zasada and J. E. Maul. "Factors affecting soil microbial community structure in tomato cropping systems". Soil Biol Biochem, vol. 42, pp. 831-841, 2010.

[54] D. C. White, H. C. Pinkart and D. B. Ringelberg. "Biomass measurements; Biochemical approaches", In: Manual of environmental microbiology (Eds). C. J. Hurst and G. R. Knudsen ASM Press, Washington, DC, pp. 91-101, 1997.

[55] E. Baath and T. H. Anderson. "Comparison of soil fungal/bacterial ratios in a pH gradient using physiological and PLFA based techniques”, Soil Biol Biochem, vol. 35, pp. 955-963, 2003

[56] K. L. Steenwerth, L. E. Jackson and F. J. Calderon. "Soil microbial community composition and land use history in cultivated and grassland ecosystems of coastal California", Soil Biol Biochem, vol. 35, pp. 489-500, 2003.

[57] J. K. Maharana and A. K. Patel. "Microbial community PLFA responses to ecosystem restoration in a chronosequeces coal mine overburden spoil and implications of soil quality", Int J Curr Microbiol Appl Sci, vol. 3(6), pp. 45-71, 2014.

[58] L. Zelles, Q. Y. Bai, R. X. Ma, R. Rackwitz, K. Winter and F. Beese. "Microbial biomass, metabolic activity and nutritional status determined from fatty acid patterns and poly hydroxybutyrate in agriculturally managed soils", Soil Biol Biochem, vol. 26, pp. 439446,1994 
[59] J. C. Zak, M. R. Willig, D. L. Moorhead and H. G. Wildman. "Functional diversity of microbial communities: a quantitative approach”, Soil Biol Biochem, vol. 26, pp. 1101-1108, 1994.

[60] P. A. Olsson. "Signature fatty acids provide tools for determination of the distribution and interactions of mycorrhizal fungi in soil", FEMS Microbiol Ecol, vol. 29, pp. 303, 1999.

[61] J. W. G. Cairney and A. A. Meharg. "Interaction between ectomycorrhizal fungi and soil saprotrophs: implications for decomposition of organic matter in soils and degradation of organic pollutants in the rhizosphere", Can J Botany. Vol. 80, pp. 803-809, 2002.

[62] A. Frostegard, A. Tunlid and E. Baath. "Changes in microbial community structure during long term incubation in two soils experimentally contaminated with metals", Soil Biol Biochem, vol. 28, pp. 55-63, 1996.

[63] C. Ratledge and S. G. Wilkinson. "Microbial Lipids". Academic Press, London, England. 1988.

[64] J. H. Parker, G. A. Smith, H. L. Fredrickson, J. R. Vestal, D. C. White. "Sensitive assay, based on hydroxy fatty acids from lipopolysaccharide lipid A for gram-negative bacteria in sediments", Appl Environ Microbiol, vol. 44, pp. 1170-1177, 1982.

[65] N. Rajendran, O. Matsuda, N. Imamura and Y. Urushigawa. "Microbial community structure analysis of euxinic sediments using phospholipid fatty acid biomarkers", J Oceanography, vol. 51, pp. 21-38, 1995.

[66] G. E. Ekosse. "Spatial distribution of iron in soils and vegetation cover close to an abandoned manganese oxide ore mine, Botswana", J Appl Sci, vol. 8(1), pp. 14-25, 2008.

[67] M. Pasayat and A. K. Patel. "Assessment of physico-chemical properties influencing mine spoil genesis in chronosequence iron mine overburden spoil and implications of soil quality”, Int J Curr Microbiol Appl Sci, vol. 4(6), pp. 1095-1110, 2015.

[68] R. J. Parkes and J. Taylor. "The relationship between fatty acid distributions and bacterial activity types in contemporary marine sediments", Estuarine Coastal and Shelf Sci, vol. 16, pp. 173-189, 1983.

[69] J. B. Guckert, C. P. Antworth, P. D. Nichols and D. C. White. "Phospholipid ester-linked fatty acid profiles reproducible assays for changes in prokaryotic community structure of estuarine sediments", FEMS Microbiol Ecol, vol. 31, pp. 147-158, 1985.

[70] M. Liao, C. L. Chen and C.Y. Huang. "Effects of heavy metals on soil microbial activity and diversity in a reclaimed mining wasteland of red soil area", J Environ Sci, vol. 17, pp. 832-837, 2005.

[71] J. Moore-Kucera and R. P. Dick. "PLFA profiling of microbial community structure and seasonal shift in soils of a Douglas-fir chronosequences", Microbial Ecol, vol. 55, pp. 500-511, 2008.

[72] R. M. C. P. Rajapaksha, M. A. Tobor-Kaplon, E. Baath. "Metal toxicity affects fungal and bacterial activities in soil differently", Appl Environ Microbiol, vol. 70(5), pp. 2966-2973, 2004.

[73] M. Potthoff, K. L. Steenwerth, L. E. Jackson, R. E. Drenovsky, K. M. Scow, R. G. Joergensen. "Soil microbial composition as affected by restoration practices in California grassland", Soil Biol Biochem, vol. 38, pp. 1851-1860, 2006.

[74] S. Yu and J. G. Ehrenfeld. "Relationships among plants, soils and microbial communities along a hydrological gradient in the New Jersey Pinelands, USA”, Annal Bot, vol. 10, pp. 185-196, 2010.

[75] C. Ahn and R. M. Peralta. "Soil bacterial community structure and physicochemical properties in migration wetlands created in the Piedmont region of Virginia (USA)", Ecol Engineer, vol. 35, pp. 1036-1042, 2009.

[76] S. M. Card and S. A. Quideau. "Microbial community structure in restored riparian soils of the Canadian Prairie pothole region", Soil Biol Biochem, vol. 42, pp. 1463-1471, 2010.

[77] N. Fierer, J. P. Schimel and P. A. Holden. "Influence of drying rewetting frequency on soil bacterial community structure", Micro Ecol, vol. 45, pp. 63-71, 2003.

[78] A. D. Peacock, M. D. Mullen, D. B. Ringelberg, D. D. Tyler, D. B. Hedrick, P. M. Gale, D. C. white. "Soil microbial community responses to dairy manure or ammonium nitrate applications", Soil Biol Biochem, vol. 33, pp. 1011-1019, 2001.

[79] D. A. Bossio and K. M. Scow. "Impacts of carbon and flooding on soil microbial communities: phospholipids fatty acid profiles and substrate utilization patterns”, Microbiol Ecol, vol. 35, pp. 265-278, 1998.

[80] H. Insam and K. H. Domsch. "Relationship between soil organic carbon and microbial biomass on chronosequences of reclamation sites", Microb Ecol, vol. 15, pp. 177-188, 1988.

[81] V. L. Bailey, J. L. Smith and H. J. Bolton. "Fungal to bacterial ratios in soils investigated for enhanced carbon sequestration", Soil Biol Biochem, vol. 34, pp. 997-1007, 2002.

[82] A. Van der Wal, J. A. van Veen, W. Smant, H. T. S. Boschker, J. Bloem, P. Kardol, W. H. van der Putten and W. de Boer. "Fungal biomass development in a chronosequence of land abandonment", Soil Biol Biochem, vol. 38, pp. 51-60, 2006.

[83] M, Pasayat and A. K. Patel. "Contribution of soil physico-chemical properties influencing microbial biomass used as biomarkers for mine spoil genesis”, Res J Pharma Biol Chem Sci, vol. 7(5), pp. 738-747, 2016.

[84] M. N. Hogberg, P. Hogberg and D. D. Myrold. "Is microbial community composition in boreal forest soils determined by pH, C:N ratio, the trees, or all three?”, Oecologia, vol. 150, pp. 590-601, 2007.

[85] M. N. Hogberg, E. Baath, A. Nordgren, K. Arnebrant, P. Hogberg. "Contrasting evicts of N availability on plant C supply to mycorrhizal fungi and saprotrophs - a hypothesis based on Weld observations in boreal forest", New Phytol, vol. 160, pp. 225-238, 2003.

[86] J. L. Smith, J. W. Doran. "Measurement and use of $\mathrm{pH}$ and electrical conductivity for soil quality analysis", In: Methods for assessing oil quality, J. W. Doran, A. J. Jones (eds), Soil Sci Soc Am, Madison, pp. 169-186, 1996.

[87] K. Goupil, K. K. Nkongolo and S. Nasserulla. "Characterization of fungal communities in limed and unlimed lands contaminated with metals: Phospholipid fatty acid (PLFA) analysis and soil respiration”, Am J Biochem Biotechnol, vol. 11(2), pp. 45-56, 2015.

[88] U. Langer and J. Rinklebe. "Priming effect after glucose amendment in two different soils evaluated by SIR and PLFA technique", Ecol Engineer, pp. 37, pp. 465-473, 2011.

[89] N. Fierer, J. A. Jackson, R. Vilgalys, R. B. Jackson. ”Assessment of soil microbial community structure by use of taxon-specific quantitative PCR assays", Appl Environ Microbiol, vol. 71, pp. 4117-4120, 2005. 
[90] B. Wang, G. B. Liu, S. Xue, B. B. Zhu. "Changes in soil physico-chemical and microbiological properties during natural succession on abandoned farmland in the Loess Plateau”, Environ Earth Sci, vol. 62, pp. 915-925, 2011.

[91] R. D. Bardgett, D. K. Leemans, R. Coak and P.J. Hobbs. "Seasonality of the soil biota of grazed and ungrazed hill grasslands", Soil Biol Biochem, vol. 29, pp. 1285-1294, 1997.

[92] N. Fierer and R. B. Jackson. "The diversity and biogeography of soil bacterial communities. Proceedings of the national academy of sciences of the United States of America", vol. 103, pp. 626-631, 2006.

[93] C. L. Lauber, M. S. Strickland, M. A. Bradford and N. Fierer. "The influence of soil properties on the structure of bacterial and fungal communities across land-use types", Soil Biol Biochem, vol. 40, pp. 2407-2415, 2008.

[94] P. Merila, R. Stromner, H. Fritze. "Soil microbial activity and community structure along a primary succession transect on the land uplift coast in western Finland", Soil Biol Biochem, vol. 34, pp. 1647-1654, 2002.

[95] P. Hogberg, A. Nordgren, N. Buchmann, A. F. S. Taylor, A. Ekblad, M. N. Hogberg, G. Nyberg, M. Ottosson-Lofvenius, D. J. Read. "Large scale forest girdling shows that current photosynthates drives soil respiration", Nature, vol. 411, pp. 789-792, 2001.

[96] M. William and C. W. Rice. "Seven years of enhanced water availability influences the physiological, structural, and functional attributes of soil microbial community", Appl Soil Ecol, vol. 35, pp. 535-545, 2007.

[97] C. Meimei, C. Baodong and M. Petra. "Plant growth and soil microbial community structure of legumes and grasses grown in monoculture or mixture", J Environ Sci, vol. 20, pp. 1231-1237, 2008.

[98] S. B. Gray, A. T. Classen, P. Kardol, Z. Yermakov, Michael and R. Mille. "Multiple climate change factors interact to alter soil microbial community structure in an old-field ecosystem", Soil Sci Soc Am J, vol. 75, pp. 2217-2226, 2011.

[99] W. Zhou, D. Hui and W, Shen. "Effects of soil moisture on the temperature sensitivity of soil heterotrophic respiration: A laboratory incubation study", Plos One, vol. 9(3), pp. 92531-92540, 2014.

[100]J. A. Ludwig and J. F. Reynolds. "Statistical Ecology: A primer in method and computing”, John Wiley and Sons, pp. 337, 1988.

[101]A. Arunachalam and H. N. "Pandey. Ecosystem restoration of Jhum fallows in Northest India: microbial C and N along altitudinal and successional gradients", Restor Ecol, vol. 11, pp. 168-173, 2003.

[102]S. S. An, Y. M. Huang and F. L. Zheng. "Evaluation of soil microbial indices along a revegetation chronosequence in grassland soils on the Loess Plateau, Northwest China", Appl Soil Ecol, vol. 41, pp. 286-292, 2009.

[103]H. H. Zhu, X. Y. He, K. L. Wang, Y. R. Su and J. S. Wu. "Interactions of vegetation succession, soil biochemical propertiesand microbial communities in a Karst ecosystem", Eur J soil Biol, vol. 51, pp. 1-7, 2012.

[104]L.E. Jackson, F. J. Calderon, K. L. Steenwerth, K. M. Scow, D. E. Rolston. "Responses of soil microbial processes and community structure to tillage events and implications for soil quality", Geoderma, vol. 114, pp. 305-317, 2003.

[105]M. Welc, E. K. Bunemann, A. Fliebbach, E. Frossard, J. Jansa. "Soil bacterial and fungal communities along a soil chronosequence assessed by fatty acid profiling", Soil Biol Biochem, vol. 49, pp. 184-192, 2012. 